\title{
BENTHIC FORAMINIFER ASSEMBLAGES FROM NORWEGIAN COLD-WATER CORAL REEFS
}

\author{
Silvia Spezzaferri ${ }^{1,3}$, Andres RüggeberG $^{2}$, Claudio Stalder $^{1}$ and Stephan Margreth ${ }^{1}$
}

\begin{abstract}
Quantitative investigations on the total (living + dead) benthic foraminiferal assemblages were performed on 32 surface-sediment samples $(0-2 \mathrm{~cm},>63-\mu \mathrm{m}$ size fraction) from water depths ranging from 110-600 m ("on-reef") to $>2000$ m ("off-reef") in the Oslo Fjord (Skagerrak Basin), the mid-Norwegian slope (Sula, Røst, and Trænadjupet reefs), and the northern coral-reef areas in Norway (Korallen, Lopphavet, Stjernsundet, and Sveinsgrunnen reefs). Seven other samples were investigated for their living (stained) and dead (unstained) assemblages. Hierarchical cluster analysis allows the recognition of five benthic species groups linked to foraminiferal microhabitats from on- and off-reef environments as follows: I) shallow "off-reef" areas of the Oslo Fjord, II) deep-sea $>1800-\mathrm{m}$ water depth, and III) bathyal between 800-1800 m, and "on-reef" areas of IV) the Skagerrak and V) the shelf and upper continental slope of the mid- and nothern Norwegian margin. The benthic foraminiferal fauna associated with the declining coral reefs in the Oslo Fjord suggests that a low amount of labile organic matter and/or nutrients reach the sea floor making the environment unfavorable for coral growth, reconfirming the previous results on direct measurements of the organic matter. This study indicates that foraminifers can be used as a tool for the characterization of cold-water coral-reef environments.
\end{abstract}

\section{INTRODUCTION}

Cold-water coral (CWC) ecosystems have worldwide occurrences, and along the European margin form widespread reefs. They were first documented from Norway in the 18th century (Pontoppidan, 1755; Linnaeus, 1758). Since these pioneering investigations, CWC reefs have been reported in the Mediterranean Sea (Zibrowius, 1980; Taviani and others, 2005; Margreth and others, 2011), the Gulf of Cadiz (e.g., Pinheiro and others, 2001; Foubert and others, 2008; Wienberg and others, 2009), and along the Irish margin (e.g., Hovland and others, 1994; de Mol and others, 2002; Kenyon and others, 2003; van Rooij and others, 2003) up to northern Norway (e.g., Mortensen and others, 1995; Freiwald and others, 1997; Hovland and others, 1998; Freiwald and others, 1999; Fosså and others, 2002; Lindberg and Mienert, 2005).

Lophelia pertusa (Linnaeus), a colonial, reef-forming scleractinian coral, is one of the dominant species in these ecosystems (Roberts and others, 2009). Along the Irish

${ }^{1}$ University of Fribourg, Department of Geosciences, Ch. du Musée 6, 1700 Fribourg, Switzerland

${ }^{2}$ Renard Centre of Marine Geology, Ghent University, Krijgslaan 281, S8, B-9000 Gent, Belgium

${ }^{3}$ Correspondence author. E-mail: silvia.spezzaferri@unifr.ch margin L. pertusa forms large coral carbonate mounds, which originated in the late Pliocene/early Pleistocene (de Mol and others, 2002; Kano and others, 2007). On the Norwegian continental shelf, since the end of the last glacial stage at $\sim 10,900 \mathrm{ka}$ (López Correa and others, 2012), L. pertusa has built elongated reef-like structures on elevated hard substrates that can reach heights of $40 \mathrm{~m}$ and lengths of several km (Freiwald and others, 1997, 1999, 2002; Lindberg and others, 2007). Here cold-watercoral distribution is controlled by pre-existing topographic highs on the sea floor, such as moraine ridges and iceberg plough-mark levees (Freiwald and others, 1999, 2002; Mortensen and others, 2001; Fosså and others, 2005). Living corals colonize the top and the upper slopes of the highs, developing reefs, and preferentially occur at water depths between 150-400 $\mathrm{m}$ with the exception of a few shallower occurrences in fjord settings. In situ dead corals are generally present along the steep reef flanks, while bio-eroded coral rubble accumulates around their bases.

These reefs provide abundant and diverse microhabitats for benthic organisms (Mortensen and others, 1995) compared to the surrounding coral-free environments (Henry and Roberts, 2007). This is especially true for suspension and filter feeders (e.g., sponges, mollusks, brachiopods, cnidarians, bryozoans, ophiuroids, and crinoids; Mortensen and others, 2001). Foraminiferal assemblages associated with these ecosystems are not well known.

Freiwald and Schönfeld (1996) described the carnivore species Hyrrokkin sarcophaga Cedhagen feeding on polyps of $L$. pertusa. Hawkes and Scott (2005) described the foraminiferal assemblage of CWCs near the Nova Scotia peninsula, Canada. They found that Discanomalina semipunctata Asano is consistently abundant on the coral but uncommon on the margin itself, making it a possible indicator of past cold-water coral Primnoa resedaeformis (Gunnerus) habitat. Recent studies on CWC mounds in the Rockall Bank and the Porcupine Seabight have shown that numerous epifaunal, benthic foraminiferal species colonize these habitats (Rüggeberg and others, 2005, 2007; Margreth and others, 2009; Schönfeld and others, 2011) and that the benthic species Discanomalina coronata (Parker and Jones) is generally associated with living CWC reefs (Margreth and others, 2009) or coral rubble in the reefs (Schönfeld and others, 2011). The latter authors documented that the foraminiferal diversity on the Porcupine Seabight (Galway and Propeller mounds) was no higher than in adjacent areas at 500-1300-m water depth.

This study focuses on benthic CWC foraminiferal assemblages in different on- and off-reef localities from northern Norway south to the Oslo Fjord (Fig. 1) and compares those occurrences with results from the Rockall Bank and Porcupine Basin off Ireland. 

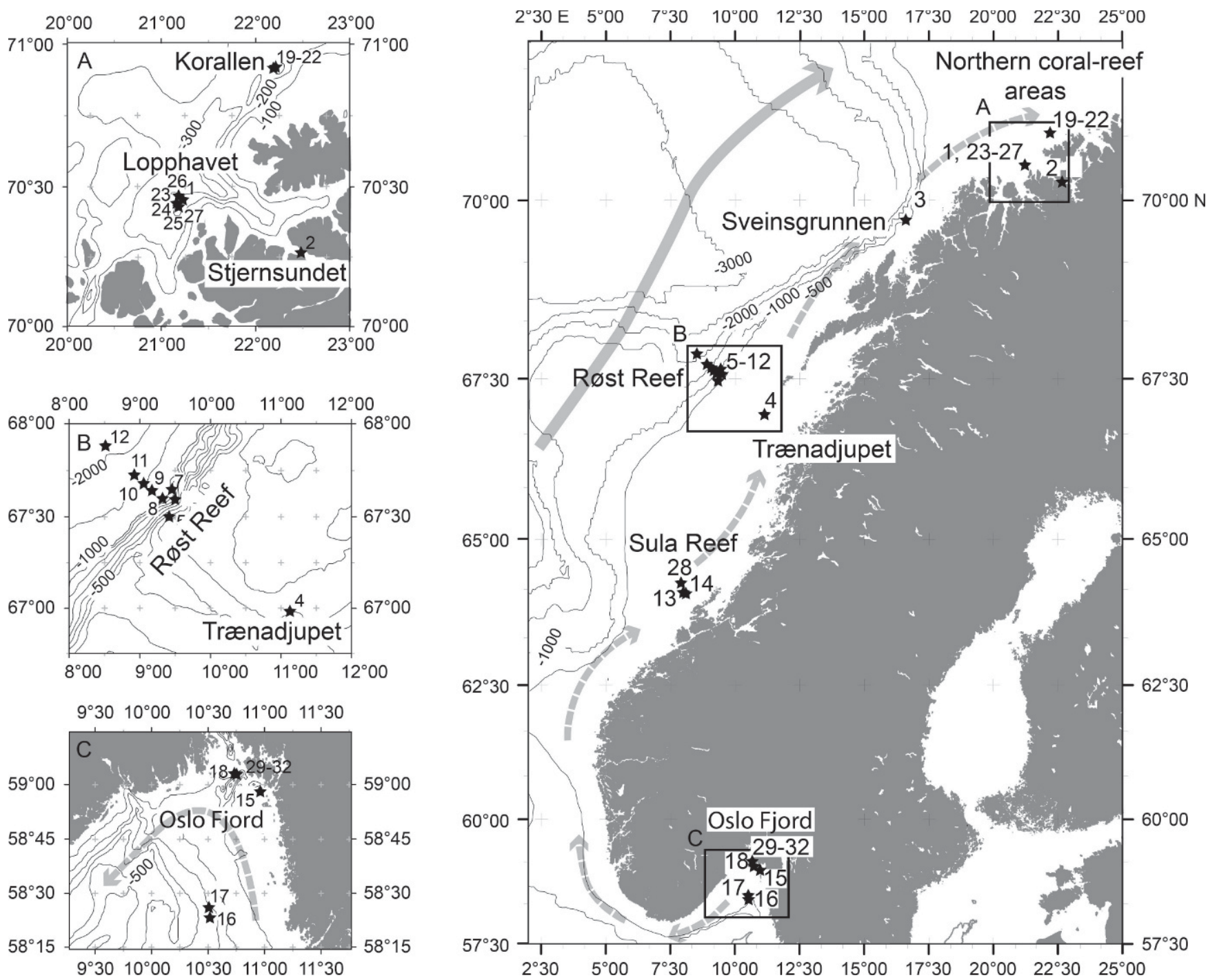

$9^{\circ} 3010^{\circ} 0010^{\circ} 3011^{\circ} 0011^{\circ} 30$

FIGURE 1. Bathymetry and location map of the surface sediment samples investigated in this study.

\section{OCEANOGRAPHIC SETTINGS AND CORAL-REEF OCCURRENCES}

Along the Norwegian coast, two northward-trending current systems control the surface water flow: the Norwegian Coastal Current (NCC) and further off the shelf the North Atlantic Current (NAC; Mork, 1981; Figs. 1, 2). The origins of the NCC are water discharge from the Baltic Sea and freshwater runoff from Norway (Mork, 1981). These low-salinity waters have a high temperature gradient between summer and winter (Sætre, 1999; Mitchelson-Jacob and Sundby, 2001). The core of the NAC flows along the Norwegian shelf break and is characterized by the northward transport of warm water $\left(6-14^{\circ} \mathrm{C}\right)$ to high latitudes. During winter the mixing of these two current systems, combined with the effects of wind and topography, are responsible for seasonal upwelling and eddies. In summer, the two current systems flow parallel to each other and the differences in their respective salinities prevent mixing (Sætre, 1999; Mitchelson-Jacob and Sundby, 2001). Blindheim (1990) grouped the NCC and the NAC current systems into the Norwegian Atlantic Current (NwAC), which flows above the Arctic Intermediate Water (AIW). The AIW is characterized by a salinity minimum at a depth of $\sim 600 \mathrm{~m}$. The Norwegian Sea Deep Water (NSDW) and the Norwegian Sea Bottom Water (NSBW) with temperatures below $0^{\circ} \mathrm{C}$ characterize the water masses on the deep continental slope (Peterson and Rooth, 1976).

Along the Norwegian margin CWC reefs occur at different water depths. In the Oslo Fjord CWCs develop between 90-140 $\mathrm{m}$ and thrive in the saline and welloxygenated oceanic Atlantic Water Inflow (AWI), only a few tens of meters below the permanently brackish surface Baltic waters (Svansson, 1975; Wisshak and others, 2005). At Sula Reef, they occur at depths of 240-315 m, at Røst Reef at 300-400 m, and at the northern-most reefs near the Nordkapp they thrive in the NwAC at 140-320 m (Fosså and others, 2002; Freiwald and others, 2004; Rüggeberg and others, 2011; Table 1; Fig. 1). 


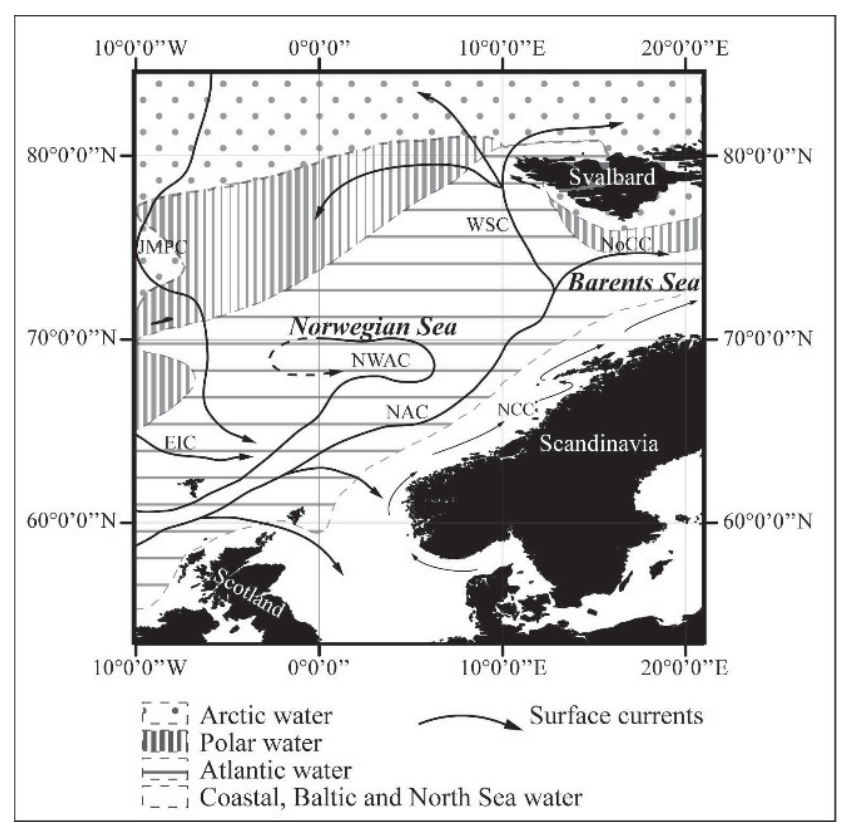

FIgURE 2. Circulation pattern in the North Atlantic and along the Norwegian margin. Currents in the Norwegian Sea and the surrounding seas modified from Yndestad and others (2008); water masses according to Mosby (1968). Surface currents: East Icelandic Current (EIC), Jan Mayen Polar Current (JMPC), North Atlantic Current (NAC), Norwegian Coastal Current (NCC), North Cape Current (NoCC), Norwegian Atlantic Current (NWAC), West Spitsbergen Current (WSC).

\section{MATERIALS AND METHODS}

Samples were collected at a relatively wide range of water depths, between 170-330 $\mathrm{m}$ at the northern coral reefs (Korallen, Stjernsundet, Lopphavet, and Sveinsgrunnen), between $300-2100 \mathrm{~m}$ on on- and off-reef sites at the midNorwegian margin (Sula Reef, Røst Reef, and Trænadjupet), and between $90-300 \mathrm{~m}$ in the Oslo Fjord (Table 1; Figs. 1, 2). The grab sampler operated by the submarine JAGO, a Giant Box corer, and Van-Veen grab were used to sample during six different cruises (Table 1). These cruises were not focused on sampling for foraminifers, and samples were not stained with rose Bengal or fixed in preservative. Only the seven samples recovered during cruise Poseidon 391 , when part of the cruise was devoted to foraminifer sampling, were preserved in a $2 \mathrm{~g}^{-1}$ rose Bengal (stained) $>70 \%$ ethanol mixture (Table 1 ), and their volume defined in the laboratory. Norwegian reefs are protected, and sampling with standard methods such as a box corer is forbidden. Thus, these seven samples from the uppermost $2 \mathrm{~cm}$ of sediment in between coral branches were retrieved with a special submarine-operated small sampler especially developed on board to avoid reef damage. When small pieces of coral branches were present in samples, benthic foraminifers were removed with a brush and stored.

Samples were dried at room temperature, weighed, and washed over a $63-\mu \mathrm{m}$ sieve. The 32 unstained samples were investigated for their total (living + dead) foraminiferal content. The seven stained samples were investigated also for their unstained (dead) and stained (living) assemblages following Alve and Murray (1995). Each sample was split to obtain at least 500 specimens. If a sample contained fewer specimens, all were counted. Stained specimens were counted separately from unstained. Video records obtained by a Remotely Operated Vehicle (ROV) and images taken with the submersible JAGO were used to characterize the seafloor.

To identify significant differences in foraminiferal assemblages, multivariate statistical analysis was performed on the quantitative foraminiferal data provided in Appendix I with the PRIMER software (version 6.1.9; Clarke, 1993). Relative percent abundance of foraminifers has been double square-root transformed to limit the contribution of the most abundant, ubiquitous species and simplify the interpretation (Field and others, 1982). The resulting similarity matrix was used to obtain the non-metric Multidimensional Scaling (nMDS) plot (Kruskal, 1964). Similarity Percentage Analysis (SIMPER) was obtained to highlight the contribution of each species to the total average (dis-) similarity between different groups and within one group (e.g., Kruskal, 1964).

\section{RESULTS}

\section{Surface Sediments}

Observations from the submersible JAGO, ROV underwater imaging, and the recovered sediments contributed to differentiate five sedimentary facies. Their descriptions integrated with the previous ones of Mortensen and others (1995, 2001), Freiwald and others (2002), and Rüggeberg and others (2011) are summarized in Table 2 and represented in Figure 3.

\section{BENTHIC FORAMINIFERA}

Two hundred and thirty benthic species were identified (Appendix 1). Their distribution along a bathymetric transect of four "on-reef" and five "off-reef" stations across the mid-Norwegian shelf at $67^{\circ} \mathrm{N}$ is shown in Figure 4. The hierarchical cluster analysis dendrogram shows clusters I-V separating at $50 \%$ of the Bray-Curtis Similarity (Fig. 5). Cluster I includes "off-reef" samples from the Oslo Fjord (northern Skagerrak Basin, 287-326-m water depth). Cluster II includes the deepest bathyal and abyssal samples from the mid-Norwegian continental slope (1824 m, $2098 \mathrm{~m})$. Cluster III includes shallower bathyal samples from the mid-Norwegian slope (889-1514 m). Cluster IV includes "on-reef" samples from the Oslo Fjord (91-140 m), and Cluster V includes samples from the reefs on the shelf and on the upper continental slope in the Norwegian Atlantic (278-761 m).

\section{DISCUSSION}

\section{DifFiculties AND Limitations}

During the processing of samples some limitations were encountered, which had to be considered before data interpretation. Many samples were received dry; thus assessment of living assemblages was not possible. Dead assemblages represent the mixing of tests from a succession of previously living assemblages that have been modified by taphonomic processes (Murray, 2000), and reflect 


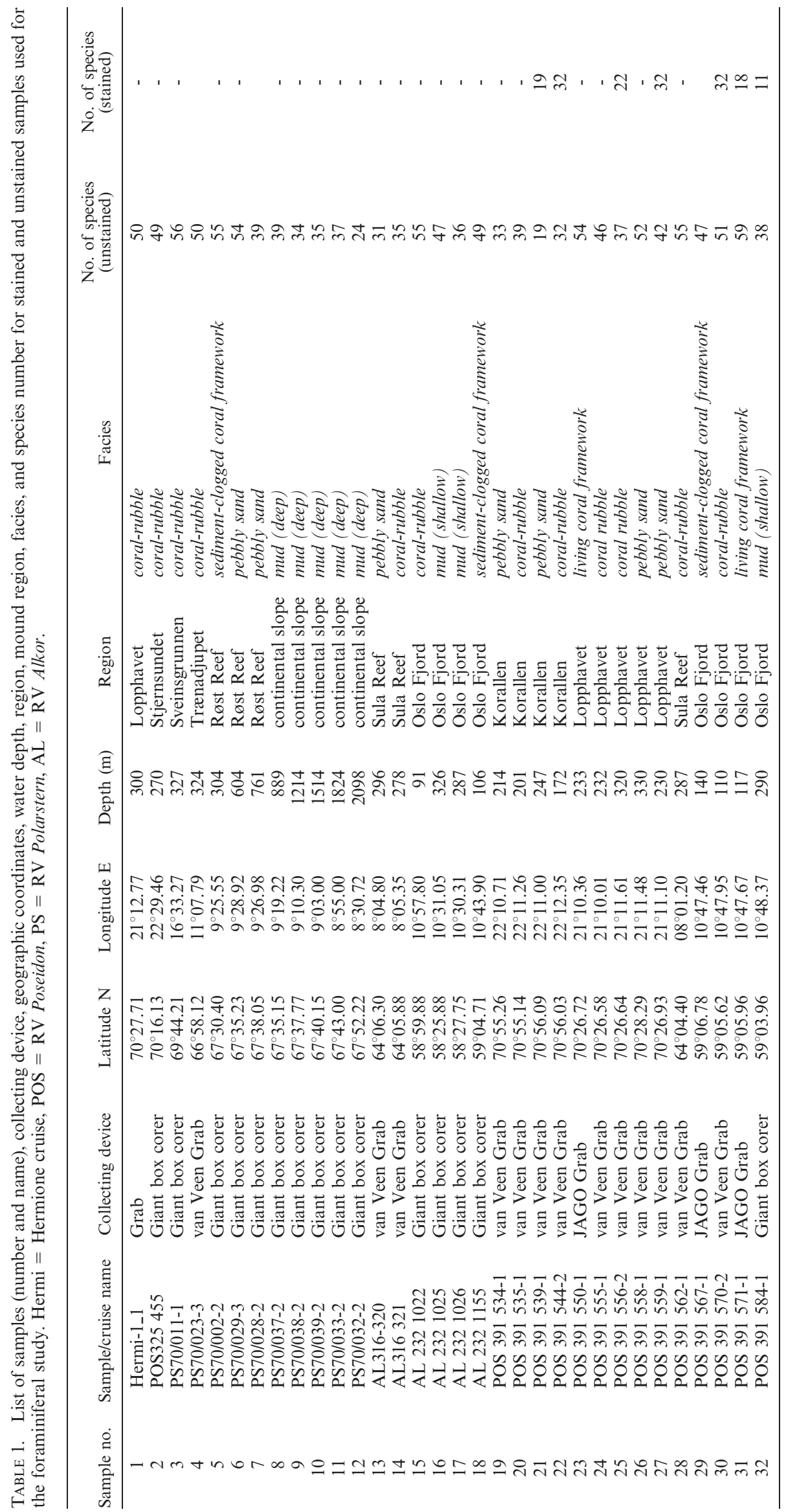


TABLE 2. Description of facies identified in a typical cold-water coral reef at Lopphavet, northern Norway (N), compared with facies identified in the Porcupine Basin (PB).

\begin{tabular}{|c|c|c|c|}
\hline Facies type & Description & Position in reef & Samples \\
\hline $\begin{array}{l}\text { Living coral framework }(N)= \\
\quad \text { living coral facies }(P B)\end{array}$ & $\begin{array}{l}\text { Large deposits of dead L. pertusa (up to } 2-\mathrm{m} \text { thick), } \\
\text { with living corals at their periphery. Living corals are } \\
\text { white or orange and covered by translucent mucus. }\end{array}$ & Top of the CWC reefs & 23,31 \\
\hline $\begin{array}{l}\text { Sediment-clogged coral } \\
\text { framework }(N)=\text { sand wave } \\
\text { and dead coral facies }(P B)\end{array}$ & $\begin{array}{l}\text { The in situ and dislocated coral framework is filled } \\
\text { with silty clay or sandy deposits enriched in skeletal } \\
\text { elements of bivalves and bio-eroded organisms. }\end{array}$ & Slopes & $5,18,29$ \\
\hline $\begin{array}{l}\text { Coral rubble }(N)=\text { dead } \\
\quad \text { coral facies }(P B)\end{array}$ & $\begin{array}{l}\text { Dead coral debris with trapped mud and silt. It appear } \\
\text { as a detrital soft-sediment substratum with remains } \\
\text { of mollusks and echinoids. Coral debris is thinner } \\
\text { and finer away from the reef. }\end{array}$ & $\begin{array}{l}\text { Lower flanks and/or at the base } \\
\text { of the living reefs. Inclination } \\
\text { generally between } 5^{\circ}-25^{\circ}\end{array}$ & $\begin{array}{r}1-4,14,15 \\
20,22,24 \\
25,28,30\end{array}$ \\
\hline $\begin{array}{l}\text { Pebbly sand }(N)= \\
\text { sand wave and dropstone } \\
\text { facies }(P B)\end{array}$ & $\begin{array}{l}\text { Sandy-silty sediments, sometimes rippled and } \\
\text { containing dropstones. Bryozoans, mollusks, } \\
\text { and coral fragments may be present. }\end{array}$ & $\begin{array}{l}\text { Transitional area between the } \\
\text { external reef facies and the } \\
\text { "off-reef" mud-facies }\end{array}$ & $\begin{array}{r}6,7,13,19 \\
21,26,27\end{array}$ \\
\hline $\begin{array}{c}\text { Mud facies (deep) }(N)= \\
\text { off-mound facies }(P B)\end{array}$ & $\begin{array}{l}\text { Fine-grained hemipelagic sediments with abundant } \\
\text { foraminifers, echinoids, mollusks, and various } \\
\text { terrigenous components. }\end{array}$ & $\begin{array}{l}\text { Water deeper than } 800 \mathrm{~m} \text { off } \\
\text { the mid-Norwegian shelves } \\
\text { and influenced by the NSDW }\end{array}$ & $8-12$ \\
\hline $\begin{array}{c}\text { Mud facies (shallow) }(N)= \\
\text { off-mound facies }(P B)\end{array}$ & $\begin{array}{l}\text { Fine-grained sediments containing foraminifers, } \\
\text { echinoids, mollusks, and various terrigenous } \\
\text { components. A color change marks the boundary } \\
\text { between the thin oxygenated surface layer and } \\
\text { the underlying dysoxic sediments. }\end{array}$ & Oslo Fjord (Skagerrak) & $16,17,32$ \\
\hline
\end{tabular}

time-integrated environmental conditions commonly spanning several years (e.g., Bouchet and others, 2012). Therefore, in this case the total fauna may be considered as a good timeaveraged assemblage (e.g., Saher and others, 2009).

The sampling procedure for the present study was hindered because grab or box-core sampling in living coral facies is forbidden for conservation reasons (Fosså and others, 2002). Only seven small samples from the reefs could be taken specifically for foraminiferal studies and were available for protoplasmic staining.

To identify living foraminifers rose Bengal was used to stain the cytoplasm (Walton, 1952). Although used in many ecological studies, its limitations are well-known. Rose Bengal is a protein stain that can be degraded slowly under certain circumstances (e.g., anoxic environments); thus, the living assemblages may be sometimes overestimated (Schönfeld and others, 2012). However, for the time being this procedure remains the most useful to identify living foraminifers (see Jorissen and others, 2007, and Schönfeld and others, 2012).

Since most samples were received already dried, monothalamous and soft-shelled foraminiferal species (e.g., Gooday and Hughes, 2002) are not considered in this study even if they are important assemblage components. Although some authors have also found that abyssal agglutinated foraminifer tests may be destroyed after drying (Schröder and others, 1988; Klitgaard Kristensen and others, 2002), Bouchet and others (2012) demonstrated that a significant positive correlation exists between the diversity of wet-picked and dry-picked assemblages from the Skagerrak (Oslo Fjord).

\section{Cold-Water Coral Ecosystems}

Cold-water corals occur exclusively in environments characterized by strong currents (e.g., Frederiksen and others, 1992; Freiwald and others, 2002; Rüggeberg and others, 2007) and input of large amounts of organic matter in the form of phytoplankton detritus (Duineveld and others, 2004). The strong currents transport food to the coral polyps and prevent them from getting smothered by fine sediment (Duineveld and others, 2004; Freiwald and others, 2004; Thiem and others, 2006; White, 2007). The organic matter feeds the zooplankton, which is also a main food source for CWCs in the form of fresh and labile organic matter (Mortensen, 2001; Freiwald and others, 2002; Duineveld and others, 2007). Lateral advection and/ or resuspension of fresh particles derived from production higher on the bank represent an additional food source for corals (Frederiksen and others, 1992; White and others, 2005; Duineveld and others, 2007).

Table 3 summarizes some of the most important parameters measured in Porcupine Seabight, Rockall Bank, the Norwegian margin, and Oslo Fjord. It shows that on the Norwegian continental margin and shelf conditions for cold-water-coral ecosystem development are generally met and are consistent with those in other North Atlantic coldwater coral sites. The modern plankton blooms and high nutrient transport caused by seasonal upwelling and eddies contribute to the high primary production at the surface, which contributes to high food flux to the sea floor. All cold-water coral sites in the North Atlantic have comparable current velocities, with mean values between $7-15 \mathrm{~cm} / \mathrm{s}$ and temporary peaks up to $45 \mathrm{~cm} / \mathrm{s}$, and good bottom-water oxygenation.

\section{Autecology of Benthic Foraminifers}

Benthic foraminifers show conspicuous patterns of habitat segregation in virtually all marine basins (e.g., Mackensen and others, 1985). The reason for this partitioning is a combination of many ecological parameters such as temperature, salinity, hydrodynamics, oxygen concentration of bottom waters, organic matter flux in different environments, and substrate (e.g., Sen Gupta, 1999; van der Zwaan and others, 1999; Gooday, 


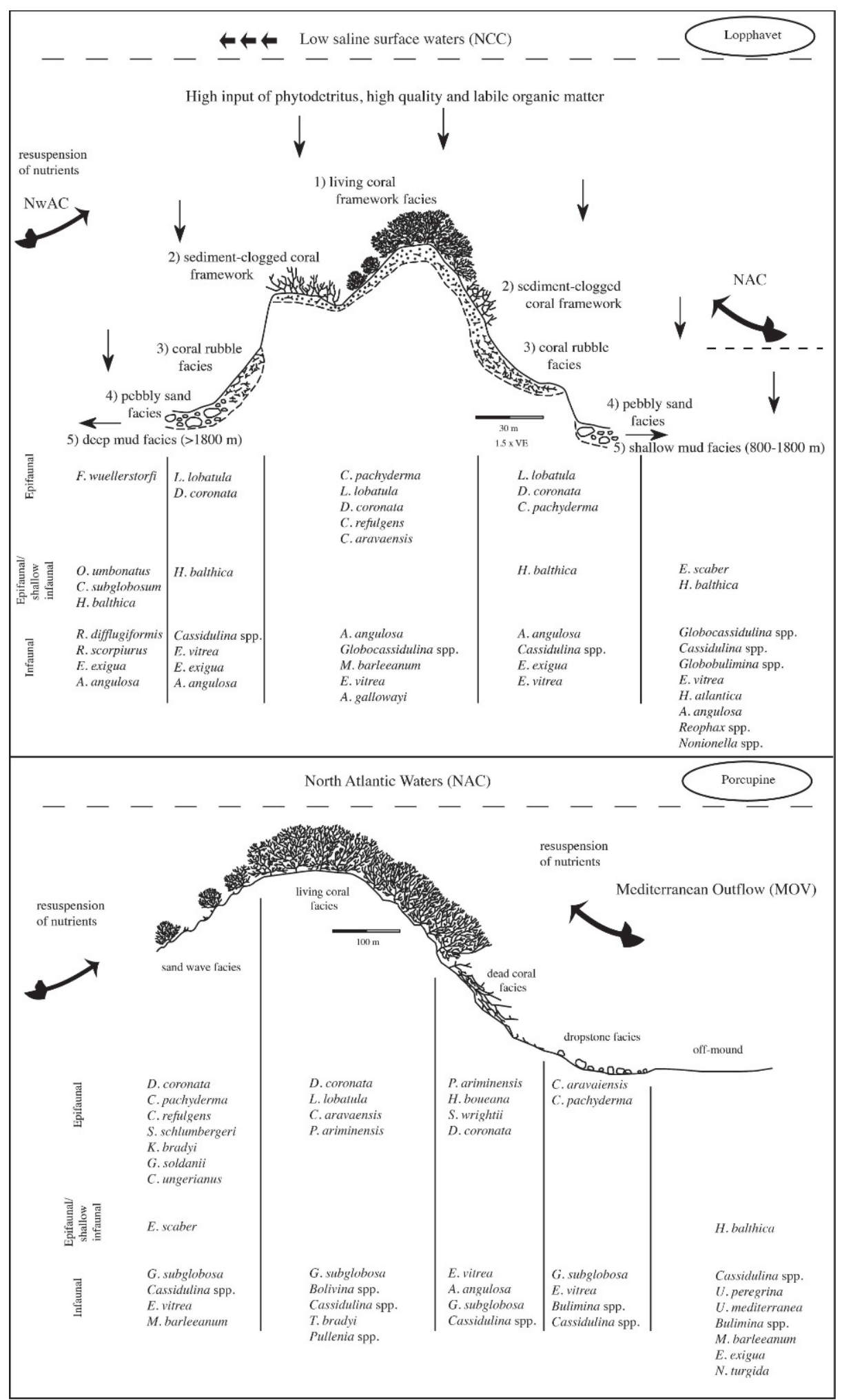

FIGURE 3. Models and distribution of benthic foraminifers on a typical cold-water coral reef at Lopphavet, northern Norway (facies model from Freiwald and others, 2002), and on cold-water coral mounds in the Porcupine Basin (modified after Margreth and others, 2009). Interpretation derived from literature data and direct observation from the submersible JAGO, GEOMAR, Kiel, Germany. 


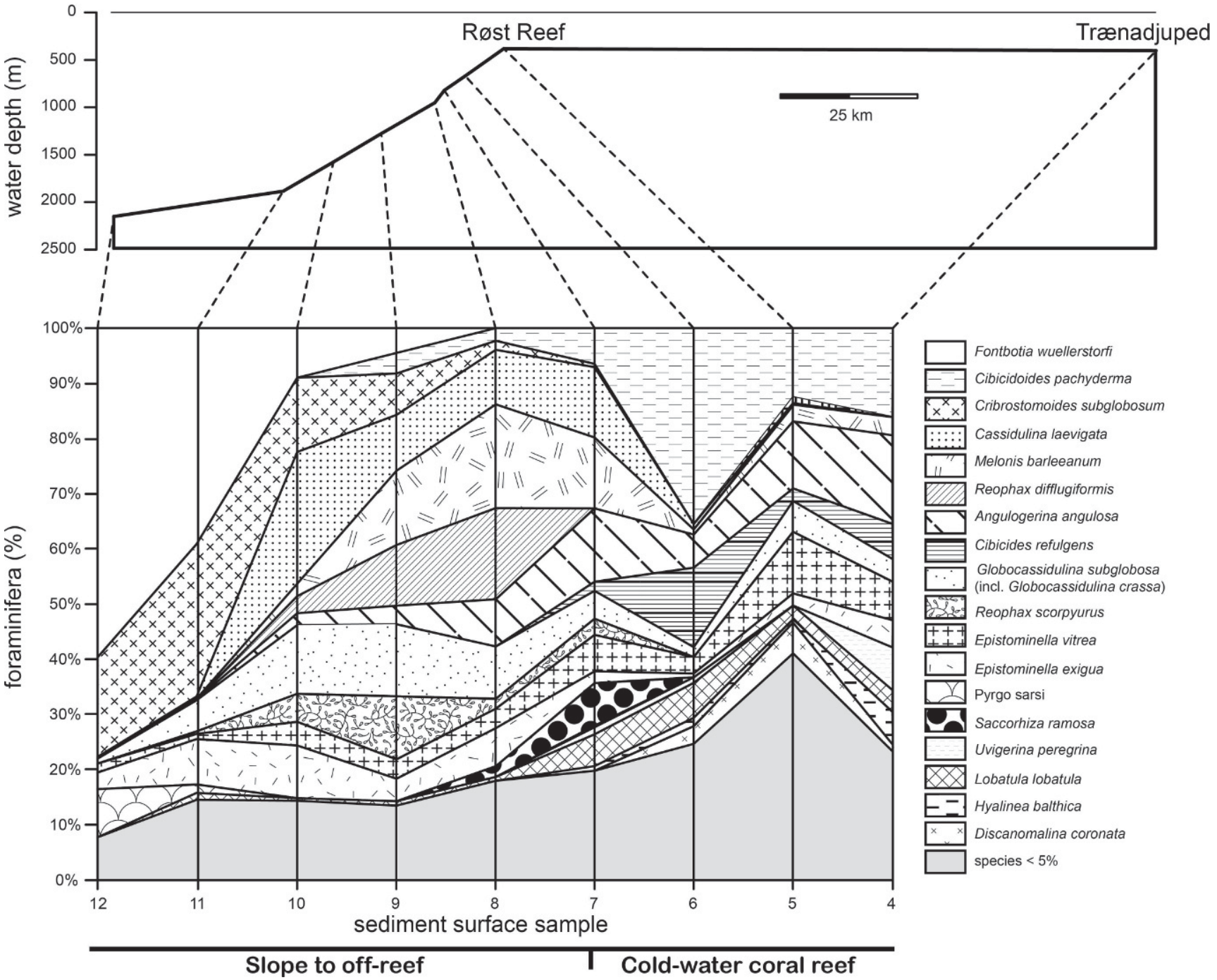

FIGURE 4. Percent distribution of the most abundant benthic foraminiferal species $(>5 \%)$ along a bathymetric transect across the mid-Norwegian shelf at $67^{\circ} \mathrm{N}$ comprising five off-reef stations (11 and 12, Cluster II; 8-10, Cluster III) and four reef associated stations (4-7, parts of Cluster V).

2003; Murray 2006). A summary of the autecology of selected benthic foraminifer species is given in Table 4 .

\section{Characterization of “ON-" AND "OfF-Reef” Sites}

Distribution patterns of benthic foraminifers from CWC ecosystems along the Norwegian margin are here linked to temperature, substrate, surface productivity, facies, hydrodynamic system, surface water conditions, and organicmatter fluxes. Schönfeld and others (2011) found that benthic foraminifer diversity is similar on carbonate mounds and in adjacent areas in the Porcupine Seabight and that the distribution of some species such as Cibicides refulgens de Montfort, Discanomalina coronata, and Uvigerina mediterranea Hofker is controlled by their specific ecological demands and microhabitat availability. The statistical treatment of our data clearly shows that benthic foraminiferal assemblages from Norwegian "off-reef" sites are different from "on-reef" sites and have lower diversity (Table 1, Fig. 3).
Clusters I-III group samples from the "Mud Facies" (deep and shallow) are characterized by fine-grained bioclastic and terrigenous sediment (Figs. 5a, b). Cluster I groups samples come from the shallow facies within the Skagerrak Basin in the Oslo Fjord. This region is the major sink for fine-grained sediments derived from the North Sea (e.g., van Weering and others, 1987; Kuijpers and others, 1993; Rodhe and Holt, 1996), and is generally bathed by Atlantic waters (Fig. 2). Dominant in Cluster I are infaunal species Globobulimina affinis (d'Orbigny), Eggerelloides scaber (Williamson), Hyalinea balthica (Schröter), Bigenerina cylindrica (Cushman), Textularia earlandi Parker, Bulimina marginata d'Orbigny, Stainforthia fusiformis (Williamson), Melonis spp., and Bolivina spp. This assemblage is tolerant of dysoxic conditions and may also feed on low quality and refractory organic matter (Fontanier and others, 2003, 2005, 2008; Murray, 2003, 2006; Alve, 2010; Alve and Goldstein, 2010; Table 4). It suggests an environment characterized by high organic-matter flux and low oxygenation, indicating that oxygenated Atlantic 


\section{a}
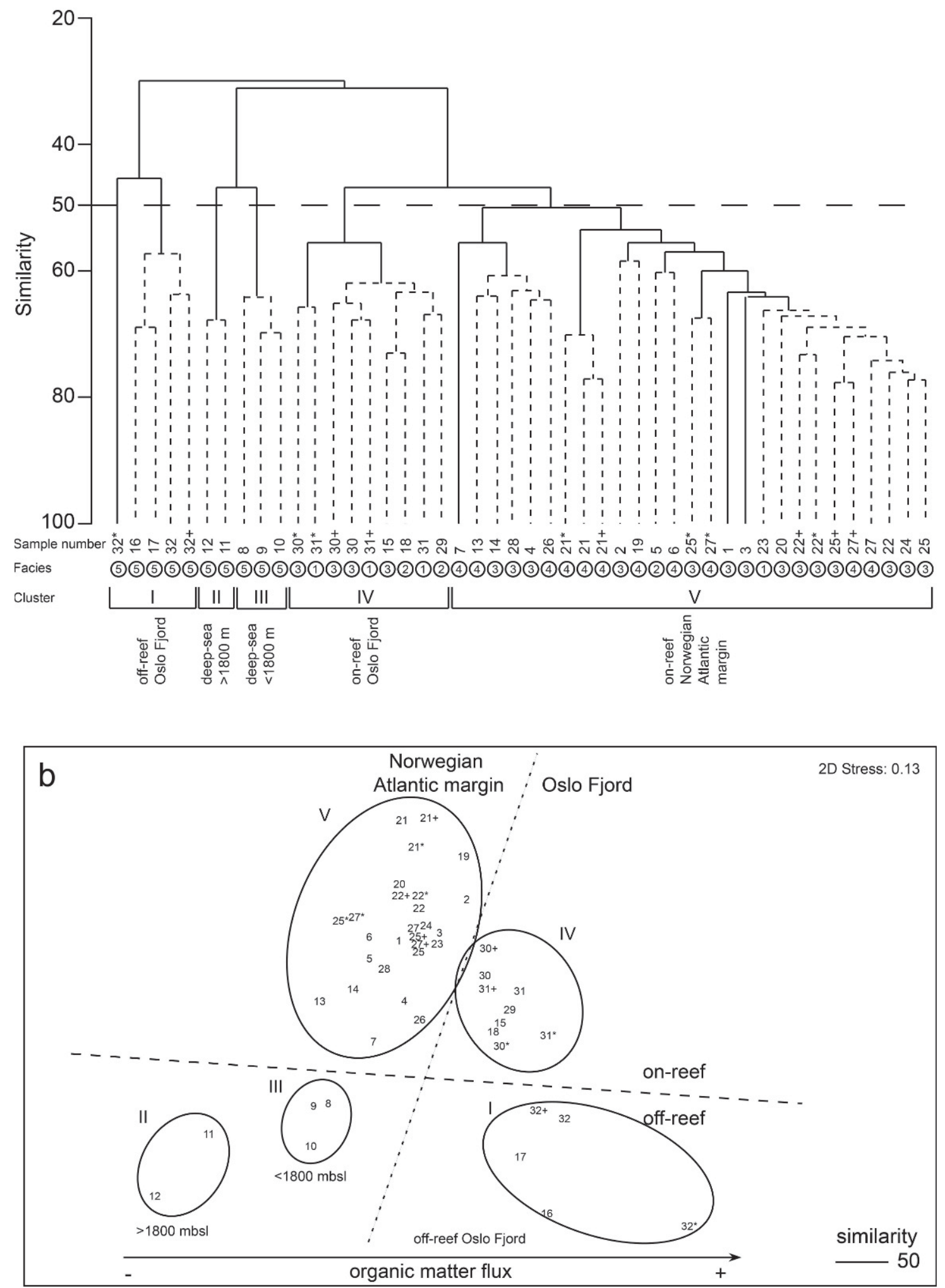

FIGURE 5. a) Hierarchical Cluster Analysis based on the Bray-Curtis similarity matrix of benthic foraminifers compositional data. Clusters I-V separate at $50 \%$ Bray-Curtis Similarity. Dashed lines indicate non-significantly differing samples (SIMPROF $\rho>0.05$ ). Non-metric MultiDimensional Scaling (nMDS) ordination obtained from Bray-Curtis similarity matrix of benthic foraminifers compositional data. The three off-reef clusters are ordered according to the "organic matter gradient" as indicated at the bottom. Lower in Cluster II (>1800 m) and higher in Cluster I (Oslo Fjord). Samples marked with * = stained (living),$+=$ unstained (dead). 
TABLE 3. Oceanographic parameters that influence the cold-water coral ecosystems in the North Atlantic according to the most recent literature.

\begin{tabular}{|c|c|c|c|c|c|}
\hline Parameter & $\begin{array}{l}\text { Porcupine } \\
\text { Seabight }\end{array}$ & $\begin{array}{l}\text { Rockall } \\
\text { Bank }\end{array}$ & $\begin{array}{l}\text { Norwegian } \\
\text { margin }\end{array}$ & $\begin{array}{l}\text { Oslo Fjord- } \\
\text { Skagerrak }\end{array}$ & Reference \\
\hline Temperature $\left({ }^{\circ} \mathrm{C}\right)$ & $9.24-9.89$ & $\begin{array}{l}(6.2) 8.57- \\
9.28(9.8)\end{array}$ & $\begin{array}{l}(6.2) 8.57- \\
9.28(9.8)\end{array}$ & $6.5-8.5$ & $\begin{array}{l}\text { Alve and Murray (1995); Mienis and others (2007); } \\
\text { Rüggeberg and Form (2007); Dullo and others } \\
\text { (2008); Flögel and others (2011); Rüggeberg and } \\
\text { others (2011); Wagner and others (2011) }\end{array}$ \\
\hline Salinity & $35.29-35.57$ & $35.13-35.4$ & $34.9-35.2$ & $35.1-35.4$ & $\begin{array}{l}\text { Mortensen (2001); Mienis and others (2007); } \\
\text { Dullo and others (2008); Flögel and others } \\
\text { (2011); Rüggeberg and others (2011); Wagner } \\
\text { and others (2011) }\end{array}$ \\
\hline $\begin{array}{l}\text { Dissolved oxygen } \\
(\mathrm{ml} / \mathrm{l})\end{array}$ & $3.76-4.60$ & $4.57-.18$ & $6.52-6.64$ & $6.3-6.6$ & Alve and Murray, (1995); Dullo and others (2008) \\
\hline $\begin{array}{l}\text { Organic matter- } \\
\text { type and/or } \\
\text { amount }\end{array}$ & fresh particles & $\begin{array}{l}\text { available to benthic } \\
\text { consumers }= \\
1.54 \mathrm{C} \mathrm{mg} \mathrm{g-1} \text { in } \\
\text { the } \mathrm{CWC} \text { area }\end{array}$ & no data & $\begin{array}{l}\text { mostly refractory } \\
\text { at } 280 \mathrm{~m}\end{array}$ & $\begin{array}{l}\text { Dauwe and Middleburg (1998); Krönke and } \\
\text { others (2004); Morigi and others (2012) }\end{array}$ \\
\hline $\begin{array}{l}\text { Current velocity } \\
(\mathrm{cm} / \mathrm{s})\end{array}$ & $9-30$, mean $8-10$ & $\leq 45$ mean $10-15$ & $7-44$ at Sula & $\begin{array}{l}30 \mathrm{~cm} / \mathrm{s} \text { at depths } \\
<100 \mathrm{~m} \text {, lower } \\
(<10 \mathrm{~cm} / \mathrm{s}) \text { in } \\
\text { deeper parts }\end{array}$ & $\begin{array}{l}\text { Eide (1979); Larsson and Rodhe (1979); Alve and } \\
\text { Murray (1995); Duineveld and others (2007); } \\
\text { Mienis and others (2007, 2009); Morigi and } \\
\text { others (2012) }\end{array}$ \\
\hline $\begin{array}{l}\delta^{15} \mathrm{~N} \text { of } L . \text { pertusal } \\
\text { feeding strategy }\end{array}$ & $\begin{array}{l}8.6-8.8=\text { corre- } \\
\text { sponding to fil- } \\
\text { ter feeding; pre- } \\
\text { dation observed } \\
\text { in laboratory }\end{array}$ & $\begin{array}{l}8.7 \pm 0.2=\text { corre- } \\
\text { sponding to } \\
\text { filter feeding; pre- } \\
\text { dation observed in } \\
\text { laboratory }\end{array}$ & filter feeding & no data & $\begin{array}{l}\text { Mortensen (2001); Duineveld and others (2007); } \\
\quad \text { van Oevelen and others (2009) }\end{array}$ \\
\hline $\begin{array}{l}\text { Surface } \\
\text { productivity }\end{array}$ & $\begin{array}{l}\text { phytoplankton } \\
\text { blooms }\end{array}$ & $\begin{array}{l}\text { induced by wind- } \\
\text { mixing nutrient } \\
\text { upwelling }\end{array}$ & $\begin{array}{l}\text { phytoplankton } \\
\text { blooms }\end{array}$ & $\begin{array}{l}\text { high and human } \\
\text { induced }\end{array}$ & $\begin{array}{l}\text { Berner and Wefer (1994); Alve and Murray } \\
\text { (1995); Sætre (1999); Lampitt and others } \\
\text { (2001); Mitchelson-Jacob and Sundby (2001); } \\
\text { White and others (2005); Duineveld and others } \\
\text { (2007) }\end{array}$ \\
\hline
\end{tabular}

waters do not reach this part of the Oslo Fjord and/or that the dysoxic layer in the sediment is close to the sea surface.

Cluster II group samples come from a water depth $>1800 \mathrm{~m}$. This region is influenced by the NSDW and AwAC, which are generally well oxygenated with $>87 \%$ saturation (Svansson, 1975; Bakker and Helder, 1993) and enter the Oslo Fjord in its deeper part ( $\sim 200 \mathrm{~m}$; e.g., Alve and Murray, 1997). However, at the location sampled a bathymetrically guided flow of the NSDW onto the inner shelf enables coral colonization between 90-140 m. Assemblages are dominated by Fontbotia wuellerstorfi (Schwager), Cribrostomoides subglobosum (Cushman), Oridorsalis umbonatus (Reuss), Pyrgo sarsi (Schlumberger), H. balthica, Reophax spp., and Epistominella exigua (Brady) (Table 5; Figs. 3, 5). Based on the ecology of these benthic foraminifers (Table 4), this cluster possibly indicates a nutrient-poor deep-sea environment, which may be influenced by strong currents ( $F$. wuellerstorfi), cold waters $(H$. balthica), and periodic pulses of fresh phytodetritus to the sea floor (F. wuellerstorfi, E. exigua, Reophax spp.).

Cluster III group samples come from the continental slope between $800-1800-m$ water depth. Dominant foraminifers include Globocassidulina subglobosa (Brady), E. exigua, Cassidulina laevigata d'Orbigny, Cassidulina spp., Reophax spp., Melonis barleeanum (Williamson), and rarer C. subglobosum (Table 5; Figs. 3, 5). Benthic assemblages of this cluster suggest high nutrient input possibly related to periodic pulses of phytodetritus.

Cluster IV group samples are from the coral reefs in the Oslo Fjord. Dominant are Lobatula lobatula (Walker and Jacob), Cassidulina spp., Melonis spp., Cibicidoides pachyderma (Rzehak), and B. marginata. This cluster suggests environments with strong bottom currents, high oxygen levels, and an elevated organic matter flux to the sea floor (Table 4).

Cluster V groups samples include the Atlantic Norwegian CWC reefs. The benthic foraminiferal fauna is dominated by $C$. pachyderma, Globocassidulina spp., D. coronata (Fig. 6), C. refulgens, L. lobatula, Angulogerina angulosa (Williamson), M. barleeanum, and Epistominella vitrea Parker. This cluster seems to indicate an environment characterized by strong bottom currents, elevated oxygen levels, and a high flux of organic matter including phytodetritus. Both Clusters IV and V apparently represent similar on-reef environments, characterized by varying abundances of epifaunal species (e.g., L. lobatula, $C$. refulgens, C. pachyderma).

The clustering of samples in separate areas of the MDS ordination suggests that conditions in the Oslo Fjord are different from those along the rest of the Norwegian margin. Direct observations from the JAGO submersible showed extensive living-reef complexes on the Norwegian margin (Freiwald and others, 2004; and authors' personal observations). However, cold-water coral ecosystems in Oslo Fjord, consisting only of small patches of living $L$. pertusa surrounded by muddy and sandy off-reef sediments, indicate that conditions for the growth of CWCs are probably not optimal.

The abundance of dead corals in the Oslo Fjord may be due to the nature of the organic matter. Kiriakoulakis and others (2008) showed that cold-water corals feed on high quality organic matter with elevated proportions of essential nutrients composed mainly of fresh and unaltered phytoplankton remains. Mortensen (2001) demonstrated 


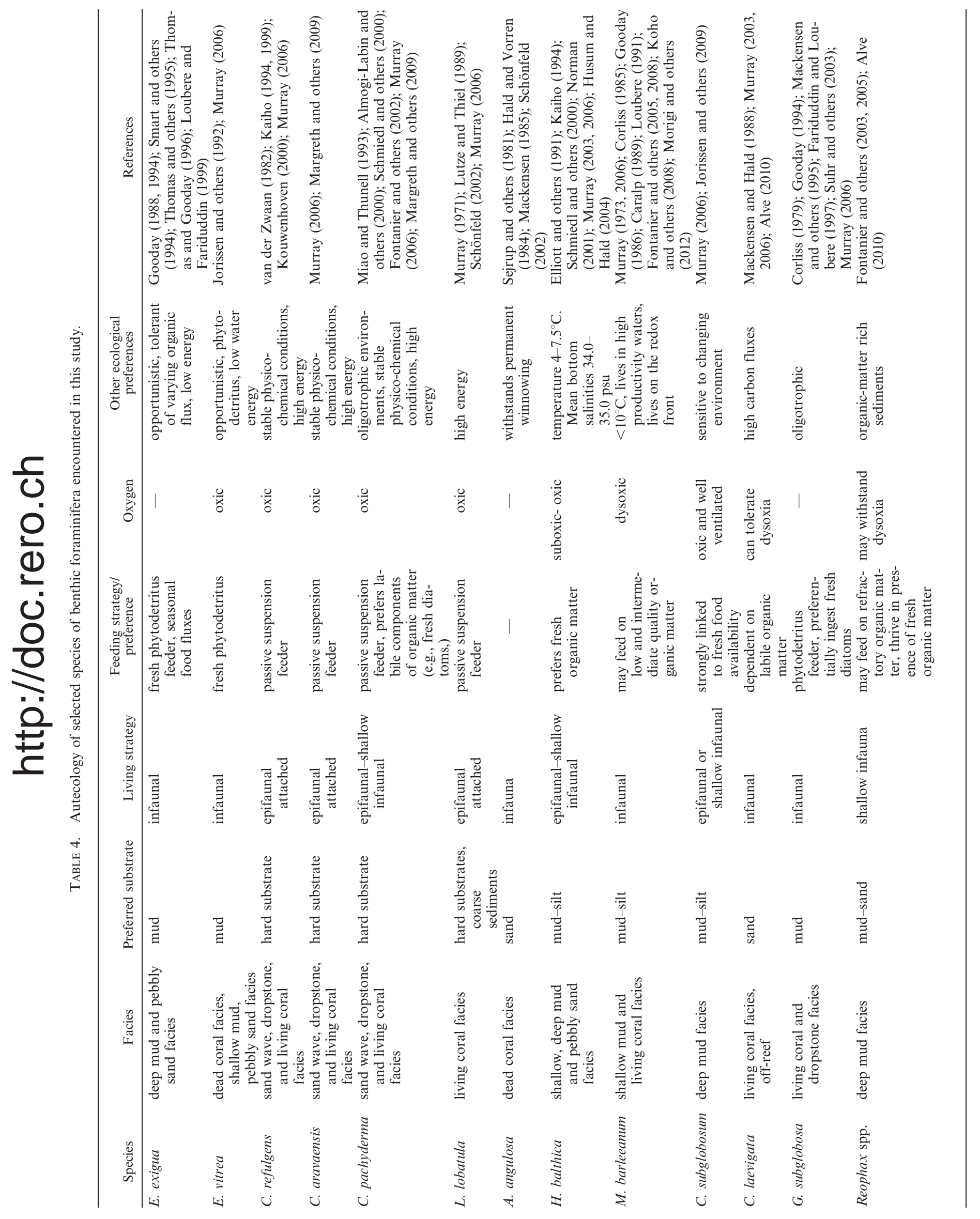




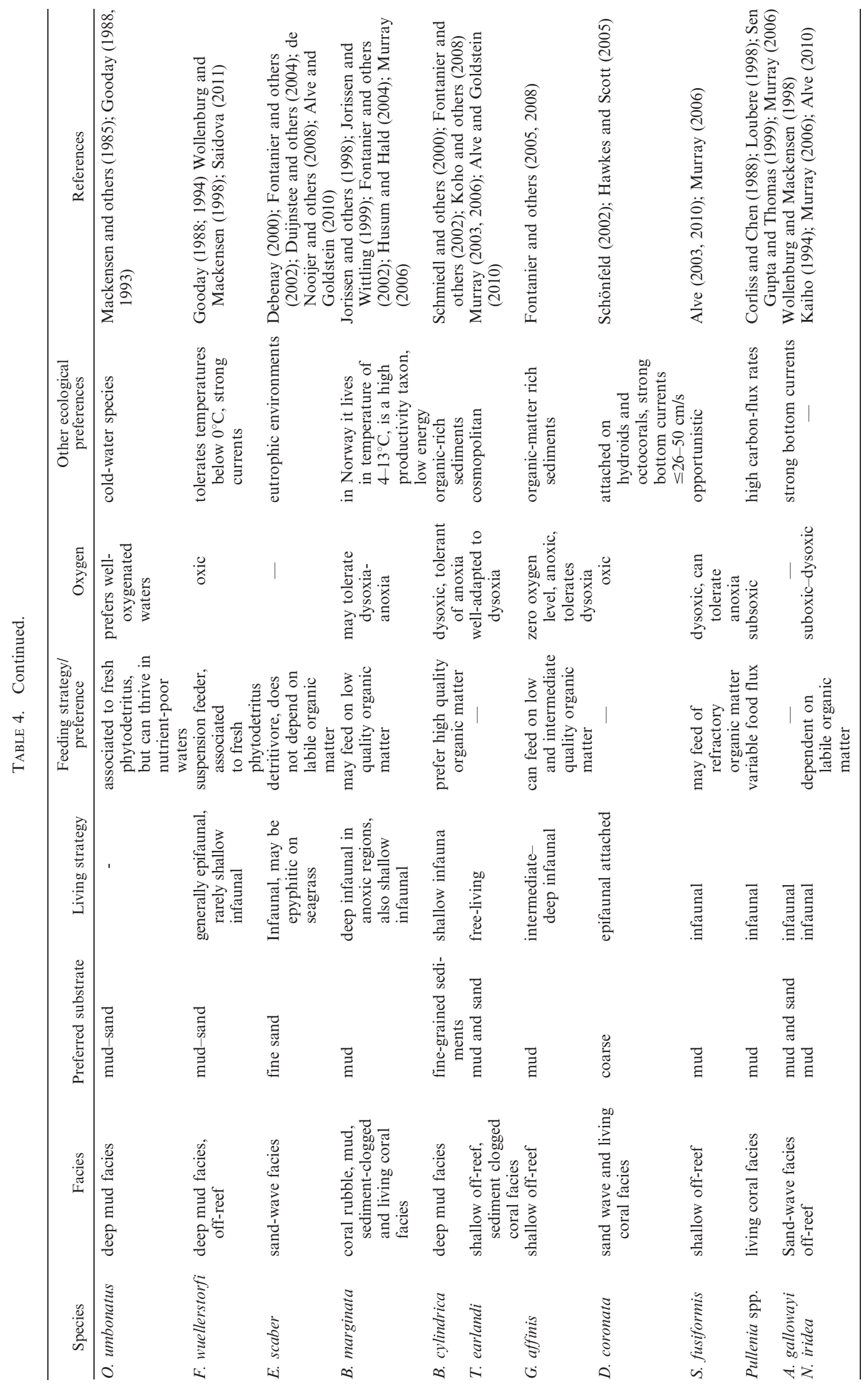


TABLE 5. List of benthic species and statistical parameters associated with the similarity in Clusters I-V. The average abundance (Av. Ab.), average similarity (Av. Sim.), contribution (\%), and cumulative contribution (Cum. \%) to the total similarity are given for each species.

\section{Cluster I}

\begin{tabular}{lccc}
\hline & & \multicolumn{2}{c}{ Average similarity: $\mathbf{5 4 . 5 3}$} \\
\cline { 2 - 4 } \multicolumn{1}{c}{ Species } & Av. Ab. & Av. Sim. & Contrib. \% \\
\hline Cassidulina spp. & 3.21 & 7.21 & 13.23 \\
Hyalinea balthica & 3.68 & 6.84 & 12.54 \\
Eggerelloides scaber & 2.41 & 5.15 & 9.44 \\
Bolivina spp. & 3 & 4.29 & 7.87 \\
Melonis barleeanum & 1.89 & 3.66 & 6.72 \\
Bulimina marginata & 1.92 & 3.51 & 6.43 \\
Textularia earlandi & 1.81 & 3.27 & 5.99 \\
Pullenia spp. & 2.12 & 2.87 & 5.27 \\
Haplophragmoides robertsoni & 1.44 & 2.81 & 5.21 \\
Globobulimina spp. & 2.72 & 2.45 & 5.79 \\
Stainforthia fusiformis & 1.46 & 1.58 & 62.21 \\
\hline
\end{tabular}

Cluster II

\begin{tabular}{rr} 
\\
\hline Average similarity: 67.85
\end{tabular}

\begin{tabular}{lcrr}
\multicolumn{1}{c}{ Species } & Av. Ab. & Av. Sim. & Contrib. \% \\
\cline { 2 - 4 } Fontbotia wuellerstorfi & 6.99 & 18.61 & 27.43 \\
Cribrostomoides subglobosum & 4.74 & 12.57 & 18.53 \\
Epistominella exigua & 2.35 & 5.34 & 7.87 \\
Oridorsalis umbonatus & 1.47 & 4.13 & 6.08 \\
Pyrgo spp. & 2.04 & 3.57 & 5.27 \\
Fissurina spp. & 1.02 & 2.92 & 4.31 \\
Lobatula lobatula & 1.01 & 2.67 & 3.97 \\
Epistominella vitrea & 1.05 & 2.66 & 63.93 \\
Cassidulina spp. & 1.06 & 2.39 & 3.93 \\
\hline
\end{tabular}

Cluster III

\begin{tabular}{ll}
\hline & Average similarity: 66.14
\end{tabular}

\begin{tabular}{|c|c|c|c|c|}
\hline & & & & \\
\hline Species & Av. Ab. & Av. Sim. & Contrib. \% & Cum. $\%$ \\
\hline Cassidulina spp. & 3.95 & 7.94 & 12.01 & 12.01 \\
\hline Reophax spp. & 4.01 & 7.93 & 11.98 & 23.99 \\
\hline Globocassidulina group & 3.41 & 7.58 & 11.46 & 35.45 \\
\hline Epistominella exigua & 2.61 & 5.32 & 8.04 & 43.49 \\
\hline Melonis barleeanum & 3.17 & 5.19 & 7.85 & 51.34 \\
\hline Epistominella vitrea & 1.94 & 4.4 & 6.66 & 57.99 \\
\hline Cribrostomoides subglobosum & 2.6 & 4.37 & 6.61 & 64.6 \\
\hline Pullenia spp. & 1.77 & 4.05 & 6.12 & 70.72 \\
\hline Angulogerina angulosa & 2.04 & 3.66 & 5.53 & 76.25 \\
\hline Cibicidoides pachyderma & 1.25 & 1.89 & 2.86 & 79.11 \\
\hline Paratrochammina challengeri & 1.01 & 1.76 & 2.67 & 81.77 \\
\hline
\end{tabular}

Cluster IV

\begin{tabular}{|c|c|c|c|c|}
\hline \multirow[b]{2}{*}{ Species } & \multicolumn{4}{|c|}{ Average similarity: 60.75} \\
\hline & Av. Ab. & Av. Sim. & Contrib. $\%$ & Cum.\% \\
\hline Lobatula lobatula & 3.5 & 5.73 & 9.43 & 9.43 \\
\hline Melonis barleeanum & 2.83 & 4.5 & 7.41 & 24.89 \\
\hline Cibicidoides pachyderma & 2.93 & 4.21 & 6.93 & 31.82 \\
\hline Melonis pompilioides & 2.53 & 4.03 & 6.64 & 38.46 \\
\hline Bulimina marginata & 2.11 & 3.1 & 5.1 & 43.55 \\
\hline Hyalinea balthica & 1.84 & 2.84 & 4.68 & 48.23 \\
\hline Gavelinopsis spp. & 1.69 & 2.43 & 4 & 52.22 \\
\hline Astrononion gallowayi & 1.5 & 2.42 & 3.98 & 56.2 \\
\hline Cibicides refulgens & 1.91 & 2.09 & 3.44 & 59.64 \\
\hline Angulogerina angulosa & 1.34 & 2.07 & 3.4 & 63.04 \\
\hline Pullenia spp. & 1.36 & 1.8 & 2.97 & 66.01 \\
\hline Globocassidulina group & 1.12 & 1.74 & 2.87 & 68.88 \\
\hline Epistominella exigua & 1.28 & 1.71 & 2.81 & 71.7 \\
\hline Spiroplectinella wrightii & 1.12 & 1.55 & 2.56 & 74.25 \\
\hline Cibicidoides aravaensis & 1.02 & 1.12 & 1.85 & 78.49 \\
\hline Hanzawaia boueana & 0.9 & 1.09 & 1.8 & 80.29 \\
\hline
\end{tabular}


TABLE 5. Continued.

\begin{tabular}{|c|c|c|c|c|}
\hline \multicolumn{5}{|l|}{ Cluster V } \\
\hline \multirow[b]{2}{*}{ Species } & \multicolumn{4}{|c|}{ Average similarity: $\mathbf{5 6 . 4 5}$} \\
\hline & Av. Ab. & Av.Sim. & Contrib.\% & Cum.\% \\
\hline Cibicidoides pachyderma & 4.19 & 7.55 & 13.37 & 13.37 \\
\hline Globocassidulina group & 2.56 & 4.61 & 8.16 & 21.53 \\
\hline Discanomalina coronata & 2.97 & 4.41 & 7.81 & 29.35 \\
\hline Cibicides refulgens & 2.49 & 4 & 7.09 & 36.44 \\
\hline Lobatula lobatula & 2.36 & 3.93 & 6.97 & 43.41 \\
\hline Angulogerina angulosa & 2.5 & 3.89 & 6.89 & 50.3 \\
\hline Cassidulina spp. & 2.09 & 3.6 & 6.37 & 56.67 \\
\hline Melonis barleeanum & 1.73 & 3.04 & 5.38 & 62.05 \\
\hline Epistominella vitrea & 1.61 & 2.21 & 3.91 & 65.96 \\
\hline Cibicidoides aravaensis & 1.39 & 1.97 & 3.49 & 69.45 \\
\hline Pullenia spp. & 1.16 & 1.65 & 2.92 & 72.37 \\
\hline Astrononion gallowayi & 1.06 & 1.47 & 2.61 & 74.98 \\
\hline Fissurina spp. & 1.01 & 1.42 & 2.52 & 77.5 \\
\hline Gavelinopsis spp. & 1 & 1.29 & 2.28 & 79.78 \\
\hline Epistoninella exigua & 0.95 & 1.2 & 2.13 & 81.91 \\
\hline
\end{tabular}
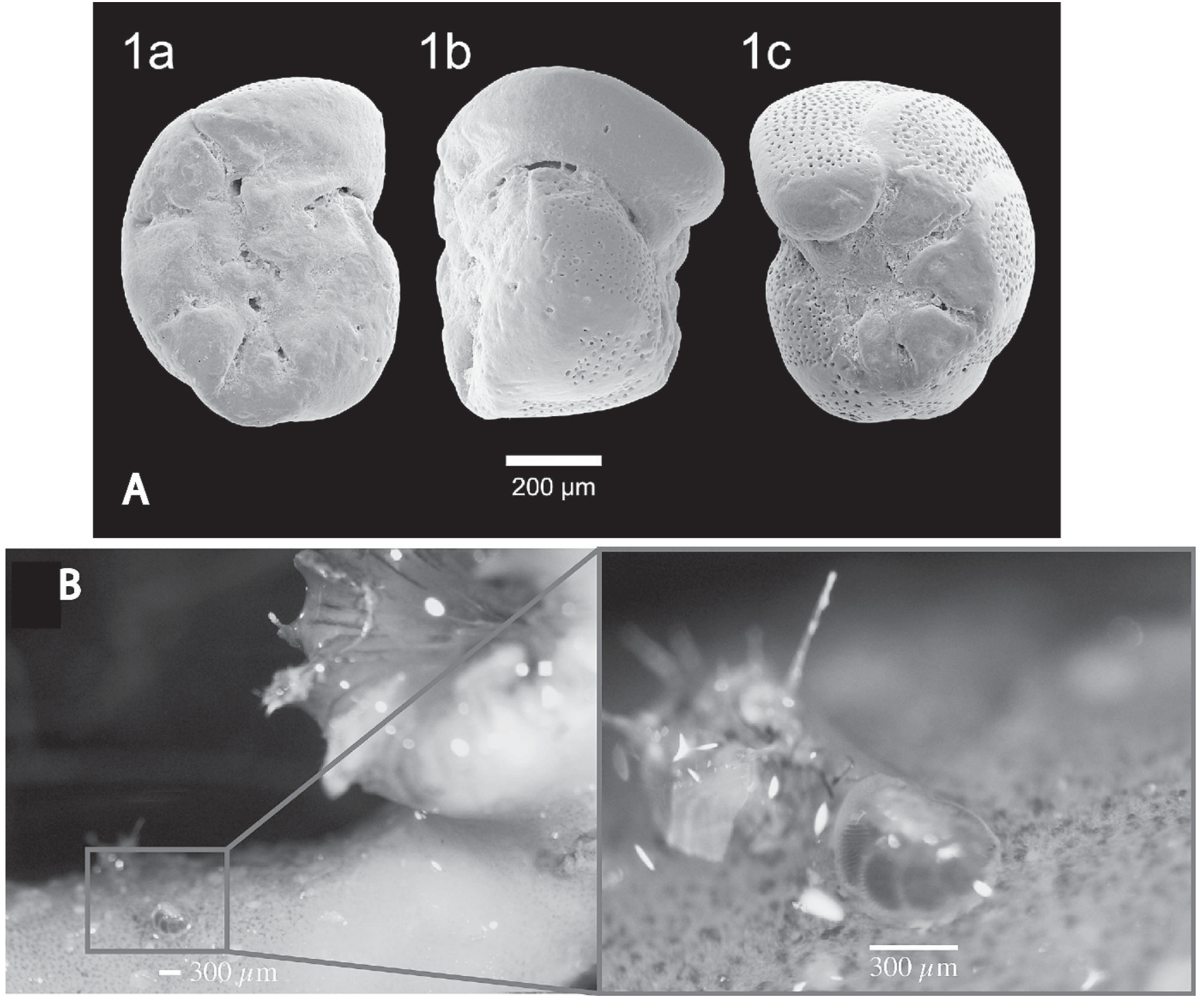

FIGURE 6. A Discanomalina coronata, SEM photomicrographs. B Living D. coronata attached to a Lophelia pertusa branch. Sampling was done by JAGO Dive 1051 at Sula Reef during cruise AL316. 
that Lophelia could feed on small organic particulates as well as on live zoobenthos and zooplankton. The Danish slope of the Skagerrak Basin is a site with high benthic fertility caused by high abundance of particulate organic matter reaching the sea floor (Alve and Murray, 1997). However, van Weering and others (1987), Dauwe and Middleburg (1998), and Krönke and others (2004) observed that the Skagerrak sediments, while relatively rich in organic matter, are of low average quality because of extensive degradation prior to deposition, and cannot support a thriving coral population.

A recent experiment of Alve (2010) on foraminiferal species collected from 320-m water depth in the Skagerrak Basin demonstrated that they do not depend on a regular supply of fresh organic matter but instead feed on degraded refractory organic matter. Based on her experiment, Alve (2010) states, "The overall moderate response to lack of fresh phytodetritus was probably due to the fact that the assemblage already was adapted to an environment dominated by poor quality food particles."

Only a few species (e.g., allogromiids, C. laevigata and Nonionella iridea Heron-Allen and Earland) are strongly dependent on a supply of fresh phytodetritus to maintain their populations (Alve, 2010). In Clusters I and IV group samples from the Skagerrak, C. laevigata and $N$. iridea are rare compared to other sites, thus suggesting that in this region, although species diversity is comparable to other areas of the Norwegian margin, the organic matter is of lower quality, confirming the biochemical results of van Weering and others (1987), Dauwe and Middleburg (1998), and Krönke and others (2004). The low quality of organic matter prevents the proliferation of organisms living within the coral framework (such as benthic meiofauna; Bongiorni and others, 2010), and therefore, the food source for corals, explaining the high abundance of dead cold-water corals in the Oslo Fjord ecosystem.

\section{Cold-Water Coral Facies Distribution and HABITATS OF BENTHIC FORAMINIFERS: Norwegian ReEFs AND IRISH MOUNDS}

Schönfeld and others (2011) showed that nutritional demands, microhabitat preferences, and ecology largely drive species abundance and distribution in the Porcupine Seabight. They observed that most of the species in the dead and living assemblages are epibenthic and that $D$. coronata is associated with coral-rubble facies, C. refulgens prefers off-mound sand veneer, and $U$. mediterranea maximum abundance is in the main depositional area on the southern flank of Galway Mound. Morigi and others (2012), on the contrary, showed that sediments surrounding the living CWCs on the Logachev Mound, Rockall Bank slope, were characterized by higher foraminiferal abundance and biodiversity than in open-slope sediments from the same area.

Margreth and others (2009) recorded abundant epifauna and benthic infauna in the living-coral-framework ecosystems from the Porcupine Basin. In particular, infaunal $M$. barleeanum, G. subglobosa, Cassidulina spp., and Gavelinopsis spp. live in the finer-sediment fraction between coral branches. Similarly along the Norwegian margin (Table 4;
Fig. 3), infaunal species are also present in the muddysandy sediments trapped by the living coral framework. In this region epifaunal benthic species are also present in the sediment-clogged coral and pebbly sand facies where dropstones and dead corals provide them with ecological niches. Uvigerinids abundant in the mud facies of the Porcupine Basin are rarer in the off-reef Norwegian study sites. This is consistent with Schönfeld and Altenbach (2005), who reported the absence of this group from the Norwegian-Greenland Sea. They relate this absence to the grazing activity of zooplankton that inhibits the deposition of the spring phytoplankton bloom in the Norwegian Sea (Bathmann and others, 1990; von Bodungen and others, 1995). Based on benthic foraminiferal distribution and sediment characterization (Table 2; Fig. 3), we find a near 1:1 correlation of sedimentary facies along the Norwegian margin $(\mathrm{N})$ in this study with those in the Porcupine Basin (PB; Margreth and others, 2009) as shown in Table 2.

In summary, cold-water-coral facies distribution is controlled by the variability of physical, chemical, and biological parameters (temperature, pressure, oxygen availability, and currents; Roberts and others, 2006), nutrient supply, availability of fresh labile organic matter (Davies and others, 2009), and salinity and density (Dullo and others, 2008), which differ in adjacent regions (e.g., Dorschel and others, 2007; Wienberg and others, 2009). The distribution of benthic foraminifers and their microhabitats is controlled by geological and environmental parameters (e.g., Jorissen and others, 1995; Fontanier and others, 2002) very similar to those controlling cold-watercoral facies distribution such as oxygen, nutrients, substrate, and current patterns. Facies and benthic foraminiferal microhabitats are similar along the Irish and Norwegian margins, although species composition and abundance may vary. In the Porcupine Basin off Ireland both microhabitats and facies can extend over hundreds of meters (Margreth and others, 2009), whereas along the Norwegian margin they can change within tens of meters or even within meters (Freiwald and others, 2002; Hühnerbach and others, 2008) (Fig. 3).

\section{CONCLUSIONS}

Cluster and nMDS analyses of benthic foraminifers along the Norwegian margin have been used to characterize the cold-water coral (CWC) ecosystems. Our results show that on the Norwegian continental margin and shelf, the conditions for CWC ecosystem development are generally met and are consistent with those in other North Atlantic CWC sites.

Analysis of relative abundance data allows recognition of 5 clusters: I) shallow "off-reef" areas of the Skagerrak Basin; II) deep-sea >1800-m water depth; III) bathyal between 800-1800 m; IV) "on-reef" areas of the Skagerrak; and V) "on-reef" areas on shelf and upper-continental slope in the Norwegian Atlantic.

The benthic fauna provides information on environmental parameters, such as substratum, currents, oxygenation, and organic matter content. In particular, benthic fauna from deep and shallow mud facies suggests high nutrient input at the sea floor, strong currents, and cold waters. 
Benthic foraminifers associated with living CWC reefs indicate an environment characterized by high energy and well-oxygenated waters with high amounts of fresh organic matter (derived from phytoplankton blooms) reaching the sea floor. The benthic foraminiferal fauna associated with coral reefs in the Skagerrak indicates that, although the flux of organic matter is high, the labile component usable for CWC growth is low, and may explain the extensive occurrence of dead corals in this area.

Benthic foraminiferal assemblages from the Porcupine Basin and the Norwegian margin show that their living strategies and microhabitats are similar, although species composition may vary. In the Porcupine Basin both microhabitats and facies can extend over hundreds of meters, whereas along the Norwegian margin they can change within tens of meters.

\section{TAXONOMIC NOTE}

In this research we retain the species concepts of Discanomalina coronata, Discanomalina japonica Asano, and Rosalina semipunctata. Medioli and Scott (1978) lumped together the planispiral D. coronata and D. japonica with the trochospiral $R$. semipunctata, stating that their morphologic differences are due to intraspecific variation resulting from different current energy, and their attached life style. Furthermore, the Discanomalina morphotypes are restricted to the shelf, and the spines of $R$. japonica are teratological features. However, they did not undertake a morphometrical study to support their hypothesis. After a careful analysis of their article we conclude that their specimens do not clearly show evidence of transitions between planispiral and trochospiral coiling, partly because the three standard SEM images of spiral, lateral, and umbilical views are not shown for all specimens that seem to be mostly trochospiral. Recent research has shown that $D$. coronata is also a deep-sea form, not restricted to the shelf, and it is abundant in cold-water coral ecosystems (e.g., Margreth and others, 2009; Schönfeld and others, 2011). It occurs together with $D$. japonica and $R$. semipunctata in the same environment.

We may argue that the two planispiral species could be lumped together under the senior synonym $D$. coronata. However, the clearly trochospiral form should be kept separate. Therefore, with the current lack of DNA evidence and/or a morphometric revision, we keep the three forms separated and retain the generic attribution for $D$. coronata, $D$. japonica, and $R$. semipunctata.

\section{ACKNOWLEDGMENTS}

This research is funded by the Swiss National Science Foundation grants 200021-103482 and 200020-131829/1. Andres Rüggeberg acknowledges funding by Deutsche Forschungsgemeinschaft (DFG), Projects TRISTAN, and Palaeo-TRISTAN (Contract Nos. Du129/37-2 and 37-3). Thanks to captains, crews, chief scientists, and scientific parties of research cruises with RV Polarstern (ARK XXII/ 1a), RV Poseidon (P325, P391), and RV Alkor (232, 316). We are very grateful to Elisabeth Alve for constructive comments on a previous version of the manuscript.

\section{REFERENCES}

Almogi-labin, A., Schmiedl, G., Hemleben, C., Siman-Tov, R., Segl, M., and Meischner, D., 2000, The influence of the NE winter monsoon on productivity changes in the Gulf of Aden, NW Arabian Sea, during the last $530 \mathrm{ka}$ as recorded by foraminifera: Marine Micropaleontology, v. 40, p. 295-319.

Alve, E., 2003, A common opportunistic foraminiferal species as an indicator of rapidly changing conditions in a range of environments: Estuarine Coastal and Shelf Science, v. 57, p. 501-514.

, 2010, Benthic foraminiferal responses to absence of fresh phytodetritus: a two year experiment: Marine Micropaleontology, v. 76, p. 67-75.

, and Murray, J. W., 1995, Benthic foraminiferal distribution and abundance changes in Skagerrak surface sediments: 1938 (Höglund) and 1992, 1993 data compared: Marine Micropaleontology, v. 25 , p. 269-288.

, and -1997 , High benthic fertility and taphonomy of foraminifera: a case study of the Skagerrak, North Sea: Marine Micropaleontology, v. 31, p. 157-175.

_ , and GoldsteIn, S. T., 2010, Dispersal, survival and delayed growth of benthic foraminiferal propagules: Journal of Sea Research, v. 63 , p. $36-51$

BAKKER, J. F., and HELdER, W., 1993, Skagerrak (northeastern North Sea) oxygen microprofiles and porewater chemistry in sediments: Marine Geology, v. 111, p. 299-321.

Bathmann, U. V., Peinert, R., Noji, T. T., and von Bodungen, B., 1990, Pelagic origin and fate of sedimenting particles in the Norwegian Sea: Progress in Oceanography, v. 24, p. 117-125.

Berner, H., and Wefer, G., 1994, Clay-mineral flux in the Fram Strait and Norwegian Sea: Marine Geology, v. 116, p. 327-345.

Blindheim, J., 1990, Arctic intermediate water in the Norwegian Sea: Deep-Sea Research, Part I, v. 35, p. 1475-1489.

Bongiorni, L., Mea, M., Gambi, C., Pusceddu, A., Taviani, M., and DANOVARO, R., 2010, Deep-water scleractinian corals promote higher biodiversity in deep-sea meiofaunal assemblages along continental margins: Biological Conservation, v. 143, p. 1687-1700.

Bouchet, V. M. P., Alve, E., Rygg, B., and Telford, R. J., 2012, Benthic foraminifera provide a promising tool for ecological quality assessment of marine waters: Ecological Indicators, v. 23, p. 66-75.

CARAlP, M. H., 1989, Size and morphology of the benthic foraminifer Melonis barleeanum: relationships with marine organic matter: Journal of Foraminiferal Research, v. 19, p. 235-245.

ClARKE, K., 1993, Non-parametric multivariate analyses of changes in community structure: Australian Journal of Ecology, v. 18, p. $117-143$.

Corliss, B. H., 1979, Taxonomy of Recent deep-sea benthonic foraminifera: Micropaleontology, v. 25, p. 1-19. , 1985, Microhabitats of benthic foraminifera within deep-sea sediments: Nature, v. 314, p. 435-438.

, and CHen, C., 1988, Morphotype patterns of Norwegian Sea deep-sea benthic foraminifera and ecological implications: Geology, v. 16, p. 716-719.

Dauwe, B., and Middelburg, J. J., 1998, Amino acids and hexosammine as indicators of organic matter degradation state in North Sea sediments: Limnology and Oceanography, v. 43, p. 782-798.

Davies, A. J., Duineveld, G. C. A., Lavaleye, M. S. S., Bergman, M. J. N., van Haren, H., and Roberts, J. M., 2009, Downwelling and deep-water bottom currents as food supply mechanisms to the cold-water coral Lophelia pertusa (Scleractinia) at the Mingulay Reef complex: Limnology and Oceanography, v. 54, p. 620-629.

de Mol, B., van Rensbergen, P., Pillen, S., van Herreweghe, K., van Rooij, D., McDonnell, A., Huvenne, V., Ivanov, M., Swennen, R., and Henriet, J. P., 2002, Large deep-water coral banks in the Porcupine Basin, southwest of Ireland: Marine Geology, v. 188, p. 193-231.

de Nooijer, L. J., Duijnstee, I. A. P., Bergman, M. J. N., and van DER ZWAAN, G. J., 2008, The ecology of benthic foraminifera across the Frisian Front, southern North Sea: Estuarine, Coastal and Shelf Science, v. 78, p. 715-726. 
Dorschel, B., Hebbeln, D., Foubert, A., White, M., and Wheeler, A. J., 2007, Hydrodynamics and cold-water coral facies distribution related to recent sedimentary processes at Galway Mound west of Ireland: Marine Geology, v. 244, p. 184-195.

Duijnstee, I. A. P., De Lugt, I. R., Vonk NoordegraAF, H., and VAN DER ZWAAN, G. J., 2004, Temporal variability of foraminiferal densities in the northern Adriatic Sea: Marine Micropaleontology, v. 50, p. 125-148.

Duineveld, G. C. A., Lavaleye, M. S. S., and Berghuis, E. M., 2004, Particle flux and food supply to a seamount cold-water coral community (Galicia Bank, NW Spain): Marine Ecology Progress Series, v. 277, p. 13-23.

, Bergman, M. J. N., De Stigter, H. C., and Mienis, F., 2007, Trophic structure of a cold-water coral mound community (Rockall Bank, NE Atlantic) in relation to the nearbottom particle supply and current regime: Bulletin of Marine Science, v. 81, p. 449-467.

Dullo, W.-Chr., Flögel, S., and Rüggeberg, A., 2008, Cold-water coral growth in relation to the hydrography of the Celtic and Nordic European continental margin: Marine Ecology Progress Series, v. 371, p. 165-171.

EIDE, L., 1979, Evidence of a topographically trapped vortex on the Norwegian continental shelf: Deep-Sea Research, Part I, v. 26, p. 601-621.

Elliott, A. J., Clarke, T., and Li, Z., 1991, Monthly distributions of surface and bottom temperatures in the northwest European shelf seas: Continental Shelf Research, v. 11, p. 453-466.

FARIDUdDIN, M., and Loubere, P., 1997, The surface ocean productivity response of deeper water benthic foraminifera in the Atlantic Ocean: Marine Micropaleontology, v. 32, p. 289-310.

Field, J. G., Clarke, K. R., and Warwick, R. M., 1982, A practical strategy for analyzing multispecies distribution patterns: Marine Ecology Progress Series, v. 8, p. 37-52.

Flögel, S., Rüggeberg, A., and Gauger, S., 2011, Water mass properties along the northern Norwegian margin, in Klages, M., and Thiede, J. (eds.), The Expedition of the Research Vessel "Polarstern" to the Arctic in 2007 (ARK-XXII/1a-c). Reports on Polar and Marine Research, Volume 627: Alfred-Wegener-Institut für Polar- und Meeresforschung in der Helmholtz-Gemeinschaft, Bremerhaven, p. 28-31.

Fontanier, C., Jorissen, F. J., Licari, L., Alexandre, A., Anschutz, P., and CARBonel, P., 2002, Live benthic foraminiferal faunas from the Bay of Biscay: faunal density, composition, and microhabitats: Deep-Sea Research, Part I, v. 49, p. 751-785.

, Chaillou, G., David, C., Anschutz, P., and Lafon, V., 2003, Seasonal and interannual variability of benthic foraminiferal faunas at $550 \mathrm{~m}$ depth in the Bay of Biscay; DeepSea Research, Part I, v. 50, p. 457-494

Anschutz, P., Gremare, A., and Griveaud, C., 2005, Live foraminiferal faunas from a $2800 \mathrm{~m}$ deep lower canyon station from the Bay of Biscay: faunal response to focusing of refractory organic matter: Deep-Sea Research, Part I, v. 52, p. 1189-1227.

, Lansard, B., Mouret, A., Buscail, R., Schmidt, S., Kerhervé, P., Buron, F., Zaragosi, S., Hunault, G., Ernoult, E., Artero, C., Anschutz, P., and Rabouille, C., 2008, Live foraminifera from the open slope between Grand Rhône and Petit Rhône Canyons (Gulf of Lions, NW Mediterranean): Deep-Sea Research, Part I, v. 55, p. 1532-1553.

FossÅ, J. H., Mortensen, P. B., and Furevik, D. M., 2002, The deepwater coral Lophelia pertusa in Norwegian waters: distribution and fishery impacts: Hydrobiologia, v. 471, p. 1-12.

- Lindberg, B., Christensen, O., Lundälv, T., Svellingen, I., Mortensen, P. B., and Alvsvåg, J., 2005, Mapping of Lophelia reefs in Norway: experiences and survey methods, in Freiwald, A., and Roberts, J. M. (eds.), Cold-Water Corals and Ecosystems: Springer-Verlag, Berlin-Heidelberg, p. 359-391.

Foubert, A., Depreiter, D., Beck, T., maignien, L., Pannemans, B., Frank, N., Blamart, D., and Henriet, J. P., 2008, Carbonate mounds in a mud volcano province off north-west Morocco: key to processes and controls: Marine Geology, v. 248, p. 74-96.

Frederiksen, R., Jensen, A., and Westerberg, H., 1992, The distribution of the scleractinian coral Lophelia pertusa around the
Faroe Islands and the relation to internal tidal mixing: Sarsia, v. 77 , p. $157-171$

Freiwald, A., and SchönfEld, J., 1996, Substrate pitting and boring pattern of Hyrrokkin sarcophaga Cedhagen, 1994 (Foraminifera), in a modern deep-water coral reef mound: Marine Micropaleontology, v. 28, p. 199-207.

, HeinRICH, R., and PÄtzold, J., 1997, Anatomy of a deepwater coral reef mound from Stjernsund, West Finnmark, northern Norway, in James, N., and Clarke, J. (eds.), Cool-Water Carbonates: SEPM Special Publication, v. 56, p. 141-161.

, Wilson, J. B., and Henrich, R., 1999, Grounding Pleistocene icebergs shape recent deep-water coral reefs: Sedimentary Geology, v. 125 , p. 1-8.

, Hühnerbach, V., Lindberg, B., Wilson, J. B., and CAmPBELL, J., 2002, The Sula Reef complex, Norwegian shelf: Facies, v. 47 , p. $179-200$.

- Fosså, J. H., Grehan, A., Koslow, T., and Roberts, J. M. 2004, Cold-Water Coral Reefs: United Nations Environmental Program-World Conservation Monitoring Centre, Cambridge, $84 \mathrm{p}$

GoodAy, A. J., 1986, Meiofaunal foraminiferans from the bathyal Porcupine Seabight (northeast Atlantic): size structure, standing stock, taxonomic composition, species diversity and vertical distribution in the sediments: Deep-Sea Research, Part I, v. 33, p. $1345-1373$

, 1988, A response by benthic foraminifera to the deposition of phytodetritus in the deep sea: Nature, v. 322, p. 70-73.

, 1994, The biology of deep-sea foraminifera: a review of some advances and their applications in paleoceanography: Palaios, v. 9, p. $14-31$.

, 2003, Benthic foraminifera (Protista) as tools in deep-water palaeoceanography: environmental influences on faunal characteristics: Advances in Marine Biology, v. 46, p. 1-90.

, and Hughes, J. A., 2002, Foraminifera associated with phytodetritus deposits at a bathyal site in the northern Rockall Trough (NE Atlantic): seasonal contrasts and a comparison of stained and dead assemblages: Marine Micropaleontology, v. 46, p. $83-110$

HALD, M., and Vorren, T., 1984, Modern and Holocene foraminifera and sediments on the continental shelf off Troms, north Norway: Boreas, v. 13, p. 133-154.

Hawkes, A. D., and ScotT, D. B., 2005, Attached benthic Foraminifera as indicators of past and present distribution of the coral Primnoa resedaeformis on the Scotian Margin, in Freiwald, A., and Roberts, J. M. (eds.), Cold-Water Corals and Ecosystems: Springer-Verlag, Berlin-Heidelberg, p. 881-894.

Henry, L. A., and Roberts, J. M., 2007, Biodiversity and ecological composition of macrobenthos on cold-water coral mounds and adjacent off-mound habitat in the bathyal Porcupine Seabight, NE Atlantic: Deep-Sea Research, Part I, v. 54, p. 654-672.

Hovland, M., Croker, P. F., and Martin, M., 1994, Faultassociated seabed mounds (carbonate knolls) off western Ireland and northwest Australia: Marine Petroleum Geology, v. 11, p. 232-246.

Mortensen, P. B., Brattegard, T., Strass, P., and Rokoengen, K., 1998, Ahermatypic coral banks of mid-Norway: evidence for a link with seepage of light hydrocarbons: Palaios, v. 13 , p. 189-200.

Hühnerbach, V., Blondel, P., Huvenne, V. A. I., and Freiwald, A., 2008, Habitat mapping of a cold-water coral reef off Norway, with a comparison of visual and computer-assisted methods to interpret sidescan sonar data, in Todd, B. J., and Greene, H. G. (eds.), Mapping the Seafloor for Habitat Characterisation: Geological Association of Canada, Special Paper 47, p. 291-302.

Husum, K., and HALD, M., 2004, Modern foraminiferal distribution in the subarctic Malangen Fjord and adjoining shelf, northern Norway: Journal of Foraminiferal Research, v. 34, p. 34-48.

JorisSEN, F. J., and WitTLing, I., 1999, Ecological evidence from livedead comparisons of benthic foraminiferal faunas off Cape Blanc (northwest Africa): Palaeogeography, Palaeoclimatology, Palaeoecology, v. 149, p. 151-170.

, Barmawidjaja, D. M., Puskaric, S., and van der ZwaAn,

G. J., 1992, Vertical distribution of benthic foraminifera in the 
northern Adriatic Sea: the relation with high organic flux: Marine Micropaleontology, v. 19, p. 131-146.

, de Stigter, H. C., and Widmark, J. G. V., 1995, A conceptual model explaining benthic foraminiferal microhabitats: Marine Micropaleontology, v. 22, p. 3-15.

-, Wittling, I., Peypouquet, J. P., Rabouille, C., and Relexans, J. C., 1998, Live benthic foraminiferal faunas off Cape Blanc, NW Africa: community structure and microhabitats: Deep-Sea Research, Part I, v. 45, p. 2157-2188.

_, Fontanier, C., and Thomas, E., 2007, Paleoceanographical proxies based on deep-sea benthic foraminiferal assemblage characteristics, in Hillaire-Marcel, C., and deVernal, A. (eds.), Proxies in Late Cenozoic Paleoceanography: Elsevier, Amsterdam, p. 263-325.

- , Bicchi, E., Duchemin, G., Durrieu, J., Galgani, F., Cazes, L., GAultier, M., and CAMPS, R., 2009, Impact of oil-based drill mud disposal on benthic foraminiferal assemblages on the continental margin off Angola: Deep-Sea Research, Part II, v. 56, p. $2270-2291$.

KaIHO, K., 1994, Benthic foraminiferal dissolved-oxygen index and dissolved-oxygen levels in the modern ocean: Geology, v. 22, p. 719-722.

, 1999, Effect of organic carbon flux and dissolved oxygen on the benthic foraminiferal oxygen index (BFOI): Marine Micropaleontology, v. 37, p. 67-76.

Kano, A., Ferdelman, T. G., Williams, T., Henriet, J. P., Ishikawa, T., Kawagoe, N., Takashima, C., Kakizaki, Y., Abe, K., Sakai, S., Browning, E. L., Li, X., and Integrated Ocean Drilling Program Expedition 307 Scientists, 2007, Age constraints on the origin and growth history of a deep-water coral mound in the northeast Atlantic drilled during Integrated Ocean Drilling Program Expedition 307: Geology, v. 35, p. 1051-1054.

Kenyon, N. H., Akhmentzhanov, A. M., Wheeler, A. J., van Weering, T. C. E., de HaAs, H., and Ivanov, M. K., 2003, Giant carbonate mud mounds in the southern Rockall Trough: Marine Geology, v. 195, p. 5-30.

Kiriakoulakis, K., Vilas, J. C., Blackbird, S. J., Aristegui, J., and WolfF, G. A., 2008, Seamounts and organic matter-is there an effect? The case of Sedlo and Seine Seamounts. Part II. Composition of suspended particulate organic matter: Deep-Sea Research, Part II, v. 56, p. 2631-2645.

Klitgaard Kristensen, D., Sjerup, H. P., and Haflidson, H., 2002, Distribution of recent calcareous benthic foraminifera in the northern North Sea and relation to the environment: Polar Research, v. 21, p. 275-282.

Koho, K. A., García, R., de Stigter, H. C., Epping, E., Koning, E., Kouwenhoven, T. J., and van Der ZwaAn, G. J., 2008, Sedimentary labile organic carbon and pore water redox control on species distribution of benthic foraminifera: a case study from Lisbon-Setúbal Canyon (southern Portugal): Progress in Oceanography, v. 79 , p. $55-82$.

Kouwenhoven, T. J., 2000, Survival under stress: benthic foraminiferal patterns and Cenozoic biotic crises: Geologica Utraiectina, v. 186 , p. $1-206$

Krönke, I., Thorsten, S., Wieking, G., and Palojärvi, A., 2004, Relationship between structural and functional aspects of microbial and macrofaunal communities in different areas of the North Sea: Marine Ecology Progress Series, v. 282, p. 13-31.

Kruskal, J. B., 1964, Multidimensional scaling by optimizing goodness of fit to a nonmetric hypothesis: Psychometrika, v. 29, p. 1-27.

KuiJPers, A., Dennegård, B., Albinsson, Y., and Jensen, A., 1993, Sediment transport pathways in the Skagerrak and Kattegat as indicated by Chernobyl radioactivity and heavy metal concentrations: Marine Geology, v. 111, p. 231-244.

Lampitt, R. S., Bett, B. J., Kiriakoulakis, K., Popova, E. E., Ragueneau, O., Vangriesheim, A., and WolfF, G. A., 2001, Material supply to the abyssal seafloor in the northeast Atlantic: Progress in Oceanography, v. 50, p. 1-4.

LARsson, A. M., and RoDHE, J., 1979, Hydrographical and chemical observations in the Skagerrak, 1975-1977: Oceanographic Institute, Gateborgs University, v. 29, p. 1-40.
LindberG, B., and Mienert, J., 2005, Sedimentological and geochemical environment of the Fugløy Reef off northern Norway, in Freiwald, A., and Roberts, J. M. (eds.), Cold-Water Corals and Ecosystems: Springer-Verlag, Berlin-Heidelberg, p. 633-650.

, Berndt, C., and Mienert, J., 2007, The Fugløy Reef at 70 degrees $\mathrm{N}$; acoustic signature, geologic, geomorphologic and oceanographic setting: International Journal of Earth Sciences, v. 96 , p. $201-213$.

LinNaeus, C., 1758, Systema Naturae per regna tria naturae, secundum classes, ordines, genera, species, cum characteribus, differentiis, synonymis, locis: Holmiae, Impensis Direct, Laurentii Salvii, Tomus 1, 10th edition, Stockholm, $824 \mathrm{p}$.

Loeblich, A. R., and TApPan, H., 1987, Foraminiferal Genera and Their Classification: Van Nostrand Reinhold Company, New York, 2. v., 1182 p. (imprinted 1988)

López Correa, M., Montagna, P., Joseph, N., Rüggeberg, A., FietzKe, J., Flögel, S., Dorschel, B., Goldstein, S. L., Wheeler, A., and Freiwald, A., 2012, Preboreal onset of coldwater coral growth beyond the Arctic Circle revealed by coupled radiocarbon and $\mathrm{U}$-series dating and neodymium isotopes: Quaternary Science Reviews, v. 34, p. 24-43.

Loubere, P., 1991, Deep-sea benthic foraminiferal assemblage response to a surface ocean productivity gradient: a test: Paleoceanography, v. 6, p. 193-204.

, 1998, The impact of seasonality on the benthos as reflected in the assemblages of deep-sea foraminifera: Deep-Sea Research, Part I, v. 45, p. 409-432.

, and FARIDUdDIN, M., 1999, Quantitative estimation of global patterns of surface ocean biological productivity and its seasonal variation on timescales from centuries to millennia: Global Biogeochemical Cycles, v. 13, p. 115-133.

Lutze, G. F., and Thiel, H., 1989, Epibenthic foraminifera from elevated microhabitats: Cibicidoides wuellerstorfi and Planulina ariminensis: Journal of Foraminiferal Research, v. 19, p. 153-158.

Mackensen, A., and Hald, M., 1988, Cassidulina teretis Tappan and C. laevigata d'Orbigny: their modern and late Quaternary distribution in northern seas: Journal of Foraminiferal Research, v. 18 , p. $16-24$.

-, SEJRUP, H., and JANSEN, E., 1985, The distribution of living benthic foraminifera on the continental slope and rise off southwest Norway: Marine Micropaleontology, v. 9, p. 275-306.

, Schmidl, G., Harloff, J., and Giese, M., 1995, Deep-sea foraminifera in the South Atlantic Ocean: ecology and assemblage generation: Micropaleontology, v. 41, p. 342-358.

Margreth, S., Rüggeberg, A., and Spezzaferri, S., 2009, Benthic foraminifera as bioindicator for cold-water coral reef ecosystems along the Irish margin: Deep-Sea Research, Part I, v. 56, p. 2216-2234.

, Gennari, G., Rüggeberg, A., Comas, M. C., Pinheiro, L. M., and SpezzAFERri, S., 2011, Growth and demise of cold-water coral ecosystems on mud volcanoes in the west Alboran Sea: the messages from the planktonic and benthic foraminifera: Marine Geology, v. 282, p. 26-39.

Medioli, F. S., and Scott, D. B., 1978, Emendation of the genus Discanomalina Asano and its implications on the taxonomy of some of the attached foraminiferal forms: Micropaleontology, v. 24 , p. 291-302.

Miao, Q., and Thunell, R. C., 1993, Recent deep-sea benthic foraminiferal distributions in the South China and Sulu seas: Marine Micropaleontology, v. 22, p. 1-32.

Mienis, F., de Stigter, H. C., White, M., Duineveld, G., De Haas, H., and van WeERING, T. C. E., 2007, Hydrodynamic controls on cold-water coral growth and carbonate-mound development at the SW and SE Rockall Trough margin, NE Atlantic Ocean: DeepSea Research, Part I, v. 54, p. 1655-1674.

De HaAs, H., and van Weering, T. C. E., 2009, Near-bed particle deposition and resuspension in a cold-water coral mound area at the southwest Rockall Trough margin, NE Atlantic: Deep-Sea Research, Part I, v. 56, p. 1026-1038.

Mitchelson-JACOB, G., and Sundby, S., 2001, Eddies of Vestfjorden, Norway: Continental Shelf Research, v. 21, p. 1901-1918.

Morigi, C., Sabbatini, A., Vitale, G., Pancotti, I., Gooday, A. J., Duineveld, G. C. A., De Stigter, H. C., Danovaro, R., and NeGri, A., 2012, Foraminiferal biodiversity associated with 
cold-water coral carbonate mounds and open slope of SE Rockall Bank (Irish continental margin-NE Atlantic): Deep-Sea Research, Part I, v. 59, p. 54-71.

Mork, M., 1981, Circulation phenomena and frontal dynamics of the Norwegian coastal current: Philosophical Transaction Royal Society of London, A., v. 302, p. 635-647.

Mortensen, P. B., 2001, Aquarium observations on the deep-water coral Lophelia pertusa (L., 1758) (Scleractinia) and selected associated invertebrates: Ophelia, v. 54, p. 83-104.

- Hovland, M. T., Brattegard, T., and Farestveit, R., 1995, Deep water bioherms of coral Lophelia pertusa at 64 degrees on the Norwegian shelf: structure and associated megafauna: Sarsia, v. 80 , p. $145-158$.

-, Hovland, M. T., Foss̊̊, J. H., and Furevik, D. M., 2001, Distribution, abundance and size of Lophelia pertusa coral-reefs in mid-Norway in relation to seabed characteristics: Journal of the Marine Biological Association of the U.K., v. 81, p. 581-597.

Mosby, H., 1968, Surrounding seas, in Somme, A. (ed.), Geography of Norden, map 7: J. W. Cappelens Forlag, Oslo, p. 18-26.

Murray, J. W., 2000, When does environmental variability become environmental change? The Proxy Record of benthic Foraminifera, in Martin, R. (ed.), Environmental Micropaleontology: Kluwer Academic/Plenum Publishers, New York, p. 7-37.

, 2003, An illustrated guide to the benthic foraminifera of the Hebridean Shelf, west of Scotland, with notes on their mode of life: Palaeontologia Electronica, v. 5, p. 1-31.

2006, Ecology and Applications of Benthic Foraminifera: Cambridge University Press, Cambridge, $426 \mathrm{p}$.

Peterson, W. H., and Rooth, C. G. H., 1976, Formation and exchange of deep-water in Greenland and Norwegian seas: DeepSea Research, Part I, v. 23, p. 273-283.

Pinheiro, L. M., Ivanov, M. K., Sautkin, A., Akhmanov, G., Magalhães, V. H., Volkonskaya, A., Monteiro, J. H., Somoza, L., Gardner, J., Hamouni, N., and Cunha, M. R., 2001, Mud volcanism in the Gulf of Cadiz: results from the TTR10 cruise: Congress on Geological Processes on Deep Water European Margins: Elsevier Science, Moscow, p. 131-151.

Pontoppidan, E., 1755, The natural history of Norway, vol. A-B: Linde, London.

Roberts, J. M., Wheeler, A. J., and Freiwald, A., 2006, Reefs of the deep: the biology and geology of cold-water coral ecosystems: Science, v. 312 , p. $543-547$.

, and CAIRns, S., 2009, Cold-Water Corals: Cambridge University Press, Cambridge, 352 p.

Rodhe, J., and Holt, N., 1996, Observations of the transport of suspended matter into the Skagerrak along the western and northern coast of Jutland: Journal of Sea Research, v. 35, p. 91-98.

RÜGGEBERG, A., and Form, A. (eds.) 2007, RV ALKOR Fahrtbericht/ Cruise Report AL 275-Geobiological investigations and sampling of aphotic coral reef ecosystems in the NE Skagerrak, 24.0330.03.2006: IFM-GEOMAR Report 10, p. 1-39.

- Dorschel, B., Dullo, C., and Hebbeln, D., 2005, Sedimentary patterns in the vicinity of a carbonate mound in the Hovland Mound Province, northern Porcupine Seabight, in Freiwald, A., and Roberts, J. M. (eds.), Cold-Water Corals and Ecosystems: Springer-Verlag, Berlin-Heidelberg, p. 87-112.

—, Dullo, C., Dorschel, B., and Hebbeln, D., 2007, Environmental changes and growth history of Propeller Mound, Porcupine Seabight: evidence from benthic foraminiferal assemblages: International Journal of Earth Science, v. 96, p. 57-72.

, Flögel, S., Dullo, C., Hissmann, K., and Freiwald, A., 2011, Water mass characteristics and sill dynamics in a polar coldwater coral reef setting at Stjernsund, northern Norway: Marine Geology, v. 282, p. 5-12.

SÆTRE, R., 1999, Features of the central Norwegian shelf circulation: Continental Shelf Research, v. 19, p. 1809-1831.

Saher, M., Klitgaard Kristensen, D., Hald, M., Korsun, S., and JørGenSEN, L. L., 2009, Benthic foraminifera assemblages in the central Barents Sea: an evaluation of the effect of combining live and total fauna studies in tracking environmental change: Norwegian Journal of Geology, v. 89, p. 149-161.

Saidova, K. M., 2011, Deep-water foraminifera communities of the Arctic Ocean: Marine Biology, v. 51, p. 65-73.
Schmiedl, G., Bovée, F. D., Buscail, R., Charrière, B., Hemleben, C., Medernach, L., and Picon, P., 2000, Trophic control of benthic foraminiferal abundance and microhabitat in the bathyal Gulf of Lions, western Mediterranean Sea: Marine Micropaleontology, v. 40, p. 167-188.

SCHÖNFELD, J., 2002, Recent benthic foraminiferal assemblages in deep high-energy environments from the Gulf of Cadiz (Spain): Marine Micropaleontology, v. 44, p. 141-162.

, and Altenbach, A. V., 2005, Late Glacial to Recent distribution pattern of deep-water Uvigerina species in the northeastern Atlantic: Marine Micropaleontology, v. 57, p. 1-24. -, Dullo, W.-Chr., Pfannkuche, O., Freiwald, A., RüggeBerg, A., Schmidt, S., and Weston, J., 2011, Recent benthic foraminiferal assemblages from cold-water coral mounds in the Porcupine Seabight: Facies, v. 57, p. 187-213.

-, Jorissen, F., Korsun, S., Alve, E., Geslin, E., Spezzaferri, S., and Members of THE FOBIMO WOrkING Group, 2012, The FOBIMO (FOraminiferal BIo-MOnitoring) initiative- towards a standardized protocol for soft-bottom benthic foraminiferal monitoring studies: Marine Micropaleontology, v. 94-95, p. 1-13.

Schroder, C. J., Scott, D. B., Medioli, F. S., Bernstein, B. B., and HESSLER, R. R., 1988, Larger agglutinated foraminifera: comparison of assemblages from central North Pacific and western North Atlantic (Nares Abyssal Plain): Journal of Foraminiferal Research, v. 18 , p. $25-41$.

Sejrup, H. P., Fjeran, T., Hald, M., Beck, L., Hagen, J., Miljeteig, I., Morvik, I., and Norvik, O., 1981, Benthic foraminifera in surface samples from the Norwegian continental margin between $62^{\circ} \mathrm{N}-65^{\circ} \mathrm{N}$ : Journal of Foraminiferal Research, v. 11, p. $277-295$.

Sen Gupta, B. K. (ed.), 1999, Modern Foraminifera: Kluwer Academic Publishers, Dordrecht, $384 \mathrm{p}$.

Smart, C. W., King, S. C., Gooday, A., Murray, J. W., and Thomas, E., 1994, A benthic foraminiferal proxy of pulsed organic matter paleofluxes: Marine Micropaleontology, v. 23, p. 89-99.

Suhr, S. B., Pond, D. W., Gooday, A. J., and Smith, C. R., 2003, Selective feeding by benthic foraminifera on phytodetritus on the western Antarctic Peninsula shelf: evidence from fatty acid biomarker analysis: Marine Ecology Progress Series, v. 262, p. $153-162$.

Svansson, A., 1975, Physical and chemical oceanography in the Skagerrak and Kattegat, 1. Open sea conditions: Fishing Board, Swedish Institute of Marine Research Report, v. 1, p. 1-88.

Taviani, M., Remia, A., Corselli, C., Freiwald, A., Malinverno, E., Mastrototaro, F., Savini, A., and Tursi, A., 2005, First geo-marine survey of living cold-water Lophelia reefs in the lonian Sea (Mediterranean basin): Facies, v. 50, p. 409-417.

Thiem, Ø., Ravagnan, E., FossÅ, J. H., and Bernsten, J., 2006, Food supply mechanisms for cold-water corals along a continental shelf: Journal of Marine Systems, v. 60, p. 207-219.

Thomas, E., and Gooday, A. J., 1996, Cenozoic deep-sea benthic foraminifers: tracers for changes in oceanic productivity?: Geology, v. 24, p. 355-358.

, Booth, L., Maslin, M., and Shackleton, N. J., 1995, Northeastern Atlantic benthic foraminifera during the last 45,000 years: changes in productivity seen from the bottom up: Paleoceanography, v. 10, p. 545-562.

VAN DER ZwaAn, G. J., 1982, Paleoecology of late Miocene Mediterranean foraminifera: Utrecht Micropaleontolological Bulletin, v. 25, p. 1-202.

, Duijnstee, I. A. P., Den Dulk, M., Jannik, N. T., and Kouwenhoven, T. J., 1999, Benthic foraminifers: proxies or problems? A review of paleoecological concepts: Earth Science Review, v. 46, p. 213-236.

van Oevelen, D., Duineveld, G., Lavaleye, M., Mienis, F., Soetaert, K., and Heip, C. H. R., 2009, The cold-water coral community as a hot spot for carbon cycling on continental margins: a food-web analysis from Rockall Bank (northeast Atlantic): Limnology and Oceanography, v. 54, p. 1829-1844.

van Rooij, D., De Mol, B., Huvenne, V., Ivanov, M., and Henriet, J. P., 2003, Seismic evidence of current-controlled sedimentation in the Belgica Mound province, upper Porcupine slope, southwest of Ireland: Marine Geology, v. 195, p. 31-53. 
van Weering, T. C. E., Berger, G. W., and Kalf, J., 1987, Recent sediment accumulation in the Skagerrak, northeastern North Sea: Netherlands Journal of Sea Research, v. 21, p. 177-189.

von Bodungen, B., Anitia, A., Bauerfeind, E., Haupt, O., Koeve, W., Machado, E., Peeken, I., Peinert, R., Reitmeier, S., Thomsen, C., Voss, M., Wunsch, M., Zeller, U., and ZeITZSCHEL, B., 1995, Pelagic processes and vertical flux of particles: an overview of a long-term comparative study in the Norwegian and Greenland seas: Geologische Rundschau, v. 84, p. 11-27.

Wagner, H., Purser, A., Thomsen, L., Jesus, C. C., and Lundälv, T., 2011, Particulate organic matter fluxes and hydrodynamics at the Tisler cold-water coral reef: Journal of Marine Systems, v. 85, p. 19-29.

WALTON, W. R., 1952, Techniques for recognition of living foraminifera: Contributions from the Cushman Foundation for Foraminiferal Research, v. 3, p. 56-60.

White, M., 2007, Benthic dynamics at the carbonate mound regions of the Porcupine Sea Bight continental margin: International Journal of Earth Science, v. 96, p. 1-9.

- Mohn, C., De Stigter, H., and Mottram, G., 2005, Deepwater coral development as a function of hydrodynamics and surface productivity around the submarine banks of the Rockall Trough, NE Atlantic, in Freiwald, A., and Roberts, J. M. (eds.), Cold-Water Corals and Ecosystems: Springer-Verlag, BerlinHeidelberg, p. 503-514.
Wienberg, C., Hebbeln, D., Fink, H. G., Mienis, F., Dorschel, B., Vertino, A., López Correa, M., and Freiwald, A., 2009, Scleractinian cold-water corals in the Gulf of Cadiz-first clues about their spatial and temporal distribution: Deep-Sea Research, Part I, v. 56, p. 1873-1893.

Wisshak, M., Freiwald, A., Lundälv, T., and Gektidis, M., 2005, The physical niche of the bathyal Lophelia pertusa in a nonbathyal setting: environmental controls and palaeoecological implications, in Freiwald, A., and Roberts, J. M. (eds.), ColdWater Corals and Ecosystems: Springer-Verlag, Berlin-Heidelberg, p. 979-1001.

Wollenburg, J. E., and Mackensen, A., 1998, Living benthic foraminiferas from the central Arctic Ocean: faunal composition, standing stock and diversity: Marine Micropaleontology, v. 34, p. $153-185$.

Yndestad, H., Turrell, W. R., and Ozhigin, V., 2008, Lunar nodal tide effects on variability of sea level, temperature, and salinity in the Faroe-Shetland Channel and the Barents Sea: Deep-Sea Research, Part I, v. 55, p. 1201-1217.

Zibrowius, H., 1980, Les scléractiniaires de la Méditerranée et de l'Atlantique nord-oriental: Mémoires Institut Océanographique de Monaco, v. 11, p. 2-84.

\section{APPENDIX 1}

Species list and quantitative data of benthic foraminifera. Generic names follow Loeblich and Tappan (1987). This Appendix can be found on the Cushman Foundation website in the JFR Article Data Repository (http://www.cushmanfoundation.org/jfr/index.html) as item number JFR2013001. 